Cambridge Archaeological Journal

http://journals.cambridge.org/CAJ

Additional services for Cambridge Archaeological Journal:

Email alerts: $\underline{\text { Click here }}$

Subscriptions: $\underline{\text { Click here }}$

Commercial reprints: Click here

Terms of use : Click here

\title{
Interaction before Agriculture: Exchanging Material and Sharing Knowledge in the Final Pleistocene Levant
}

Tobias Richter, Andrew N. Garrard, Samantha Allock and Lisa A. Maher

Cambridge Archaeological Journal / Volume 21 / Issue 01 / February 2011, pp 95 - 114

DOI: 10.1017/S0959774311000060, Published online: 31 January 2011

Link to this article: http://journals.cambridge.org/abstract_S0959774311000060

How to cite this article:

Tobias Richter, Andrew N. Garrard, Samantha Allock and Lisa A. Maher (2011). Interaction before Agriculture: Exchanging Material and Sharing Knowledge in the Final Pleistocene Levant. Cambridge Archaeological Journal,21, pp 95-114 doi:10.1017/ S0959774311000060

Request Permissions : $\underline{\text { Click here }}$ 


\title{
Interaction before Agriculture: Exchanging Material and Sharing Knowledge in the Final Pleistocene Levant
}

\author{
Tobias Richter, Andrew N. Garrard, \\ Samantha Allock \& Lisa A. Maher
}

\begin{abstract}
This article discusses social interaction in the Epipalaeolithic of southwest Asia. Discussions of contact, social relationships and social organization have primarily focused on the Pre-Pottery Neolithic and are often considered to represent typical hallmarks of emergent farming societies. The hunter-gatherers of the final Pleistocene, in particular those of the Early and Middle Epipalaeolithic, have more rarely been the focus of such discussions. In this article we consider evidence for interaction from the Azraq Basin of eastern Jordan, to question the uniqueness of the Neolithic evidence for interaction. We argue that interaction between differently-constituted groups can be traced within the Early Epipalaeolithic of the southern Levant, suggesting that it is of far greater antiquity than previously considered.
\end{abstract}

In the prehistory of the Levant, discussions of social interaction continue to focus primarily on the Neolithic and later periods (Belfer-Cohen \& Bar-Yosef 2000; although see Watkins 2008), despite some debate about interactions (social or otherwise) of anatomically modern humans and Neanderthals during the Middle Palaeolithic (e.g. Bar-Yosef 1988; Henry 1994; Kaufman 1999; 2001; Rak 1993; Shea 2003). Indeed, some authors have suggested that during the Pre-Pottery Neolithic B (PPNB) new, more complex forms of social interaction arose, which in themselves - apart from or in direct relation to economic changes - define the Neolithic as a new, significant departure in human history and development (e.g. Bar-Yosef 2001; 2002; Bar-Yosef \& Belfer-Cohen 1989; Cauvin 1994; 2000; Simmons 2007; Watkins 2003; 2008; 2010). Similarities in various cultural expressions - architecture, burial customs, artefacts, trade and exchange of exotic items - have been used to track these interactions and to discuss the nature of social organization. While Bar-Yosef (2001; 2002; 2008; Bar-Yosef \& Belfer-Cohen 1989) has described this from the perspective of the PPNB interaction sphere', Watkins $(2003 ; 2008 ; 2010)$ has preferred to discuss it as 'peer-polity interaction' or the emergence of supra-regional networks. For
Watkins $(2010,622)$ the emergence of human cognitive abilities and symbolic behaviour are explained by people's agglomeration in ever larger communities, going beyond the smaller social groups of the Palaeolithic. Asouti $(2006,118-19)$ recently criticized both approaches as being too overtly associated with the concepts of diffusionism and regionalism, arguing that interaction spheres are too easily confused with ethnic or cultural macro-scale forms of social organization. These discussions seem to rely on the same broad assumption: interaction during the PPNB was more complex, differently organized, intensive and commonplace, and existed on more numerous and diverse levels than that during preceding periods. Likewise, Hodder $(2007,108)$ has argued that the emergence of agricultural production and sedentism would have been impossible without 'a changed relation to time and history'. He argues that hunter-gatherer social relations were short-term and immediate, and attributes changes in how people conceptualized social relationships in time and space to have emerged during the Late Epipalaeolithic Natufian (c. 14,700-12,000 cal. вр) in the southern Levant. For him, this development is evident in an ever-increasing dependency on 'things' and the social relations in which objects were interdepend- 
ently involved. This dependency, in turn, triggered a changed perception of time, memory and history that facilitated the emergence of Neolithic settlements, economies and cosmologies (Hodder 2007, 108). The evidence for interactions derives from the exchange of material culture (e.g. the 'obsidian trade' or greenstone beads), common themes in symbolic expressions (such as figurines), related types of architecture, artefact types and the spread of domesticated plants and animals. Interaction traceable through the exchange of material culture, symbolic themes or economic practices is considered to apply at the inter-group scale, whereas intra-group social interaction is reconstructed from settlement layouts, burial practices or the existence of 'special-purpose' buildings, such as the Jericho tower or various buildings interpreted as 'shrines' or communal buildings (e.g. Hole 2002; Kuijt 2000a,b; 2002; Rollefson 2004).

This cursory overview shows that qualitatively or quantitatively more complex social interactions within and between communities are considered a defining factor of the Neolithic 'way of life'. It could be said then that interaction has helped to define the Neolithic as a new and radically different era, distinguishing it from the lives of hunter-gatherers before. Furthermore, the increasing level of interaction is considered to be directly related to fundamentally altered forms of social organization, including the emergence of social inequalities and hierarchical, stratified societies.

When we compare the preceding Epipalaeolithic period (c. 23,000-12,000 cal. BP) to this rich discussion of interaction in the Neolithic, we are tempted to ask whether there was any meaningful social interaction between and within social groups at all. At least this would be suggested by the scant attention paid to such questions in most of the literature on the Epipalaeolithic. The near total lack of a debate on this issue (but see e.g. Bar-Yosef 1989) reflects an almost stigmatic contradiction between how the Neolithic and the Epipalaeolithic are viewed and interpreted. If addressed at all, researchers focus primarily on the Late Epipalaeolithic (Natufian) in its role as a direct economic and cultural precursor to the Neolithic (Bar-Yosef 1998; 2004; Bar-Yosef \& Belfer-Cohen 1992; 2000; Bar-Yosef \& Meadow 1995; Belfer-Cohen 1991; Goring-Morris \& Belfer-Cohen 1998; Perrot 1966; Valla 1975; 1995). Henry $(1989,208)$, for example, proposed a model of social interaction in the Late Epipalaeolithic based on a matrilineal social organization and exchange of marriage partners between groups. Because the Natufian is seen as a complex hunting and gathering society, discussions of social interaction are considered more applicable here. Indeed, the comparatively abundant and varied inventory of portable figurative art objects known from the Natufian, as well as a rich record of graves that include elaborate grave goods and burial practices, have facilitated such discussions of social organization and hierarchies (Belfer-Cohen 1995; Boyd 2001; Byrd \& Monahan 1995; Wright 1978). Prior to the PPNB, social interaction is considered to have been more sporadic - due to lower population numbers - and primarily based on kinship. Leaving aside the Late Epipalaeolithic, one could argue that the disparity where the Early and Middle Epipalaeolithic is concerned reflects a dichotomy between how archaeologists have dealt with hunting and gathering societies, on the one hand, and farmers on the other (e.g. Barnard 2004; Boyd 2002; 2004; Gamble 2004; Ingold 1992; Pluciennik 2002; 2004). We have to ask ourselves whether we really want to imply that only the more 'advanced' farming communities of the Neolithic were involved in the creation of elaborate forms of interaction. Facing a similarly dichotomous perspective in the context of the Mesolithic and Neolithic in Britain, Richard Bradley was led to comment that 'successful farmers have social relations with one another, while hunter-gatherers have ecological relations with hazelnuts' $(1984,11)$. One only needs to replace 'hazelnuts' with 'cereal grasses' to make this statement applicable to southwest Asia.

In this article, we look at inter-group interaction in the Epipalaeolithic of the Azraq Basin in eastern Jordan to move beyond this dichotomy. The region has been a key area for research on final Pleistocene cultural transformations and provides a wide range of evidence for discussion (Betts 1991; 1998; Garrard 1991; 1998; Garrard et al. 1988; 1994a; 1996; Garrard \& Byrd 1992; Muheisen 1983; 1988a). We argue that existing and new data from a number of research projects provide ample evidence for social interaction between different communities of late Pleistocene hunters and gatherers, which have significant implications for how we consider their development.

For the purpose of this article we follow the conventional definition of the Epipalaeolithic in southwest Asia. Beginning at around 23,000 cal. вP and lasting until c. 12,000 cal. BP, the period is characterized by an increase in microliths amongst the retouched chipped stone tool component, accompanied by a shift towards intensive bladelet production. Several overviews of the Final Pleistocene Levant have been published and the reader is referred to these for a more detailed synthesis of the period (Bar-Yosef 1970; 1981; 1987; 1989; 2002; 2004; 2008; Bar-Yosef \& Belfer-Cohen 1989; 1991; 1992; 2000; Bar-Yosef \& Meadow 1995; 
Byrd 1994; 1998; Fellner 1995a,b; Goring-Morris 1987; 1995; Goring-Morris \& Belfer-Cohen 1998; Henry 1989; Olszewski 2001; Schyle 1996; Valla 1995).

Here we offer no specific definition of 'interaction', beyond its literal meaning. Social interaction between individuals and groups can take many diverse forms, from exchange, trade, armed or violent conflict, exchange of marriage partners, co-operation in subsistence practices, or group aggregations relating to political negotiations or ceremonial and ritual activities. These are more often than not difficult to pin down with much precision in deep prehistory. Nevertheless we will highlight the scope and character of these interactions in as much detail as we feel is empirically possible. Keeping with the term social interaction assures a 'useful ambiguity' for the argument we seek to develop here. In tracing interactions we are dependent on the material record of human action in our study region. Needless to say, this is a fragmented and incomplete palimpsest of human occupations and is therefore inherently biased. While we acknowledge the limitations of this data we hope to show that by considering a wide range of evidence and comparing it against each other that it is possible to interpret the material traces with a view to interaction.

\section{The study area}

The Azraq Basin occupies c. 12,000 $\mathrm{km}^{2}$ of the eastern steppe and desert of the Transjordanian plateau. Stretching from the Jebel Druze region in southern Syria to northern Saudi Arabia, the basin occupies the majority of the semi-arid to arid region of modernday north-central Jordan (Fig. 1). At the heart of the basin lies the Azraq Oasis, a shrinking wetland once populated by a wide range of plants and animals and fed by a series of copious springs (Nelson 1973). Excavations at several sites throughout the basin since the late 1970s and examination of sedimentary sequences suggest that local conditions in the basin during the latter part of the Last Glacial Maximum and the subsequent final Pleistocene were amenable, with localized marshlands existing in several locales (Byrd \& Garrard 1989; Garrard 1998; Garrard et al. 1988; Macumber 2001). Research on the prehistory in the Azraq Basin began in earnest during the late 1970s and continued throughout the 1980s and early 1990s (Betts 1988; 1991; 1998; Byrd 1988; Byrd \& Garrard 1989; Copeland \& Hours 1989; Garrard 1991; 1998; Garrard \& Byrd 1992; in prep.; Garrard et al. 1977; 1985; 1986; 1987; 1988; 1994a,b; 1996; Muheisen 1983; 1988a,b,c; Rollefson 1983; Rollefson et al. 1997). More recent field research has begun to expand on this existing picture by adding new sites and inventories and by re-investigating previously excavated sites (Maher et al. 2007; Richter \& Röhl 2006; Richter et al. 2007; 2010a,b; Rollefson et al. 1999; 2001; Wasse \& Rollefson 2005).

The Azraq Basin is notable for preserving evidence for two of the most substantial open-air Epipalaeolithic sites known in southwest Asia. Jilat 6 (Byrd \& Garrard 1989; Garrard 1998; Garrard \& Byrd 1992; Garrard et al. 1988; 1994a) and Kharaneh IV (Maher et al. 2007; Muheisen 1983; 1988a,b,c) comprise total surface areas of c. 19,000 $\mathrm{m}^{2}$ and $22,000 \mathrm{~m}^{2}$, respectively (Fig. 2). Excavations have demonstrated a considerable intensity of occupation at both sites showing multiple stratified occupation surfaces and producing lithic artefacts in the hundreds-of-thousands. Stratigraphy, radiometric dating and artefact typologies show that Kharaneh IV, at least, was repeatedly re-occupied over the course of $c .3000$ years, displaying a unique recurrence of human occupancy at a single location. Apart from these two sites, other Epipalaeolithic sites in the Azraq Basin are significantly smaller and characterized by more shallow accumulations of cultural deposits (Garrard et al. 1994a). Although many are visible as surface scatters of lithic artefacts, most contain subsurface cultural deposits and also have relatively dense accumulations of material culture. This inventory of final Pleistocene sites provides a rich and diverse body of evidence which can be used to examine interaction. To do so, we will draw on a variety of primary sources of evidence: settlement patterns, chipped stone artefact industries and their spatial distribution, the procurement of raw materials for ground-stone tools and their transportation, as well as data from sea shells and their distribution at different sites in the Azraq Basin and beyond.

\section{Lithic industries}

The Early and Middle Epipalaeolithic in the Azraq Basin is characterized by a unique array of lithic industries, and their patterned spatial distribution. Research into the final Pleistocene of southwest Asia over the last 70 years or so has led to the definition of a number of lithic industries based on differences both in lithic typology as well as technology (for details see Byrd 1994; Bar-Yosef 1970; Bar-Yosef \& Vogel 1987; GoringMorris 1987; 1995; Olzsewski 2001; see Table 1).

During the Early Epipalaeolithic we can broadly distinguish two major groups of assemblages in the Azraq Basin (Fig. 3 \& Table 2). Those from Kharaneh IV Phase B, and the assemblage from 'Ayn Qasiyya Area 


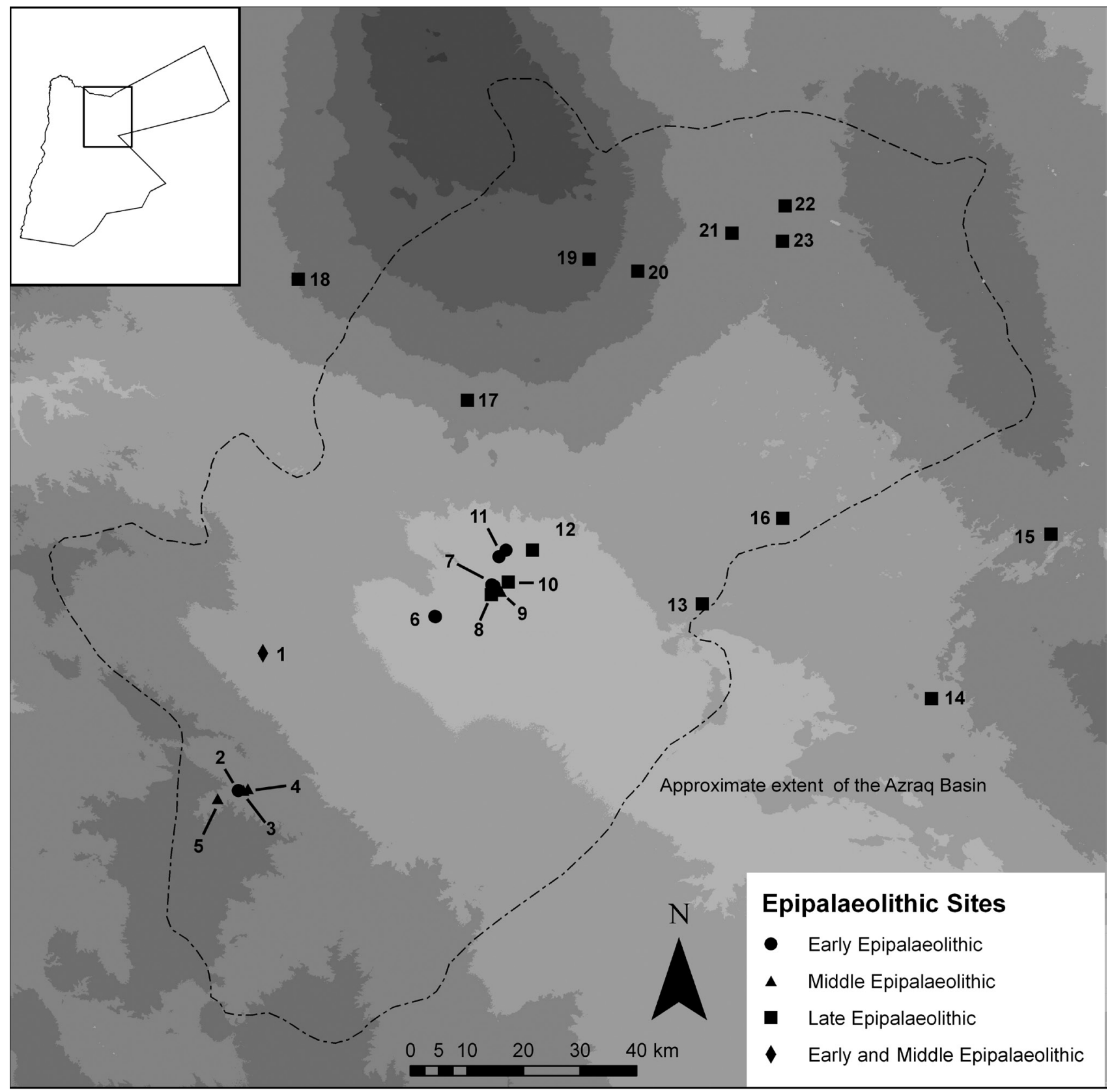

Figure 1. Distribution of principal Epipalaeolithic sites in the Azraq Basin, eastern Jordan: 1) Kharaneh IV; 2) Jilat 6; 3) Jilat 8; 4) Jilat 22; 5) Jilat 10; 6) Uwaynid 14 \& 18; 7) 'Ayn Qasiyya \& Azraq 17; 8) Azraq 18; 9) AWS48;

10) Bawabah; 11) Azraq ed-Druze sites; 12) Azraq ed-Druze 3; 13) Jebel Qurma; 14) Jebel Tharwa; 15) Jebel Subhi; 16) Qa' Mejalla; 17) Huwaynit; 18) Wadi 'Ajib; 19) Mughr al-Jawa; 20) Khallat Anaza; 21) Shubayqa I; 22) Shubayqa II; 23) Shubayqa III.

$\mathrm{A}$ and $\mathrm{B}$, show clear similarities (Richter in press; Richter et al. 2007; 2010a). By contrast, other Early Epipalaeolithic sites (Jilat 6 lower, Uwaynid 14 lower and upper, Uwaynid 18 upper phase, and 'Ayn Qasiyya Area D) fall into a second, contemporary group (Byrd 1988; Byrd \& Garrard 1989; Garrard \& Byrd in prep.;
Garrard et al. 1994a; Richter et al. 2010a). Comparing these assemblages on a wider, inter-regional scale, they can be assigned to the Kebaran (Kharaneh IV Phase A \& B, 'Ayn Qasiyya Area A \& B) and Nebekian (Jilat 6 lower, Uwaynid 14 lower and upper, Uwaynid 18 upper, 'Ayn Qasiyya Area D) industries (Bar-Yosef 


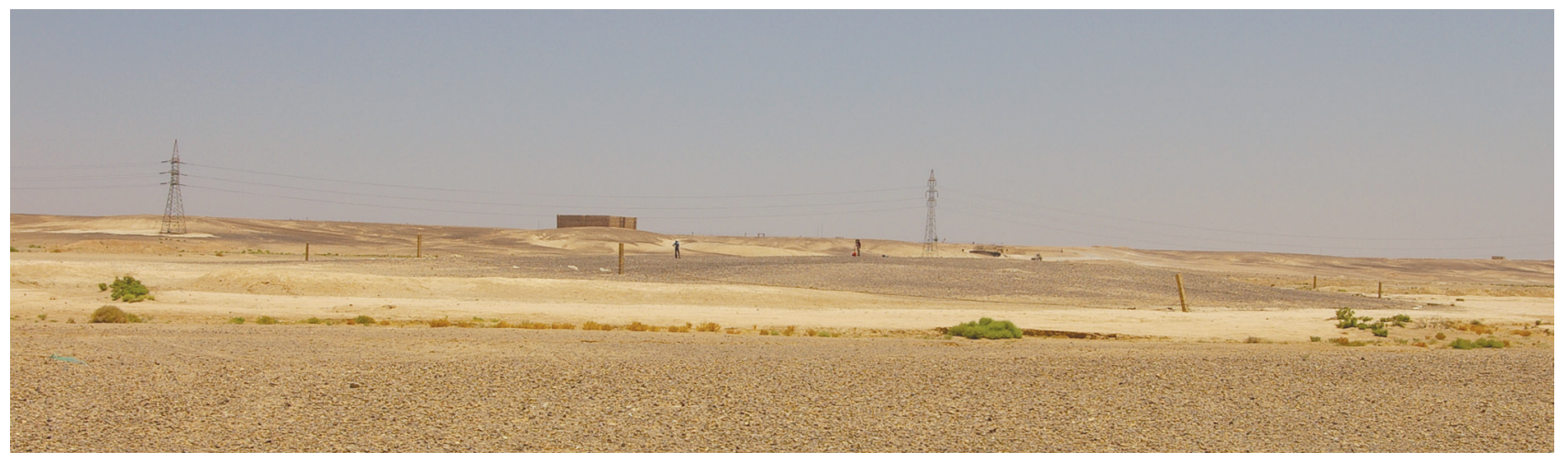

Figure 2. The Early and Middle Epipalaeolithic 'mega'-site Kharaneh IV in the middle distance between the concrete posts (the eighth-century Qasr Kharaneh is visible in the background).

Table 1. Schematic outline of the chronology and distribution of lithic industries in the southern Levant between 23,000-11,000 cal. вр.

\begin{tabular}{|c|c|c|c|}
\hline \multirow{2}{*}{$\begin{array}{l}\text { Years } \\
\text { cal. BP }\end{array}$} & \multirow{2}{*}{ Archaeological phases } & \multicolumn{2}{|c|}{ Lithic industries } \\
\hline & & Mediterranean Levant (West) & Arid Levant (East \& Negev/Sinai) \\
\hline 23,000 & \multirow{6}{*}{ Early Epipalaeolithic } & \multirow[t]{3}{*}{ Masraqan/ Late Ahmarian } & \multirow{3}{*}{$\begin{array}{c}\text { Nebekian } \\
\text { Masraqan/ Late Ahmarian }\end{array}$} \\
\hline 22,000 & & & \\
\hline 21,000 & & & \\
\hline 20,000 & & \multirow{3}{*}{$\begin{array}{l}\text { Kebaran } \\
\text { Nizzanian }\end{array}$} & \multirow{3}{*}{$\begin{array}{l}\text { Kebaran } \\
\text { Nizzanian }\end{array}$} \\
\hline 19,000 & & & \\
\hline 18,000 & & & \\
\hline 17,000 & \multirow{3}{*}{ Middle Epipalaeolithic } & \multirow{3}{*}{ Geometric Kebaran } & Geometric Kebaran \\
\hline 16,000 & & & Mushabian \\
\hline 15,000 & & & Early Ramonian \\
\hline 14,000 & \multirow{4}{*}{ Late Epipalaeolithic } & \multirow{4}{*}{$\begin{array}{l}\text { Early Natufian } \\
\text { Late Natufian } \\
\text { Final Natufian }\end{array}$} & \multirow{4}{*}{$\begin{array}{c}\text { Terminal Ramonian } \\
\text { Late Natufian } \\
\text { Harifian }\end{array}$} \\
\hline 13,000 & & & \\
\hline 12,000 & & & \\
\hline 11,000 & & & \\
\hline
\end{tabular}

1989; Byrd 1994; 1998; Goring-Morris 1995; GoringMorris \& Belfer-Cohen 1998; Olszewski 2001; 2006). A later sub-phase, present at two sites, is the Early Epipalaeolithic Qalkhan at Jilat 6 middle phase and Azraq 32 (Garrard \& Byrd in prep.). ${ }^{1}$

Stratigraphically-later assemblages can be identified with the Nizzanian industry (Jilat 6 upper phase, Kharaneh IV C, and Azraq 17 Trench 1: Goring-Morris 1995, 154-5, fig. 8). ${ }^{2}$ Post-Nizzanian industries of the incipient Middle Epipalaeolithic are known from a number of sites in the Azraq Basin. More or less, clearly identifiable Geometric Kebaran assemblages are Kharaneh IV D, AWS 48 and Wadi Jilat 28 (Garrard \& Byrd in prep.; Muheisen 1983; 1988a,c; Muheisen \& Wada 1995). Jilat 8 and 22 upper can be more readily identified with the Mushabian industry (Garrard et al. 1994a; Garrard \& Byrd in prep.), while the assemblages from Jilat 10 and Jilat 22 lower and middle do not fit any particular known profile. C14 dates from many of these sites place them firmly in the Middle Epipalaeolithic time frame (Garrard et al. 1994a).

Representative Late Epipalaeolithic lithic assemblages are known from three locations in the southern Azraq Oasis, as well as a number of surface collections elsewhere in the Azraq Basin. The sites from which inventories have been reported - Azraq 18, Mugharet al-Jawa, Khallat Anaza, Jebel Subhi, Shubayqa and Bawabah (Bawwab al-Ghazal) - all have broadly comparable lithic artefact inventories (Betts 1998; Rollefson et al. 1999). Unfortunately, so far no C14 dates have been obtained from any Natufian sites in the Azraq Basin. This makes it difficult at present to place these artefact inventories in an absolute chronological framework.

In sum, excavations at Epipalaeolithic sites in the Azraq Basin have revealed a remarkable degree of technological and typological diversity. What is noticeable about this variability is that it is not only tempo- 
Tobias Richter et al.

Table 2. Overview of the Azraq Basin lithic industries.

\begin{tabular}{|c|c|c|c|c|c|}
\hline \multirow[t]{2}{*}{ Period } & \multirow[t]{2}{*}{ Site/Phase } & \multicolumn{2}{|c|}{$\begin{array}{l}\text { Microburin } \\
\text { technique }\end{array}$} & \multirow[t]{2}{*}{ Diagnostic retouched elements } & \multirow[t]{2}{*}{ Lithic industry } \\
\hline & & Yes & No & & \\
\hline \multirow{12}{*}{ 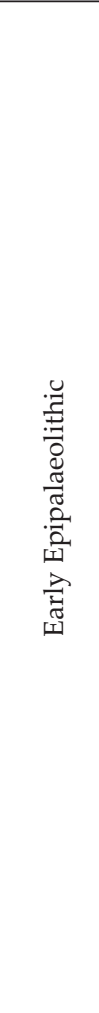 } & Kharaneh IV Phase A & & $x$ & $\begin{array}{l}\text { Bladelets with partial or complete fine } \\
\text { retouch, microgravettes with bipolar } \\
\text { retouch }\end{array}$ & $\begin{array}{l}\text { Final Ahmarian/Masraqian } \\
\text { or Early Kebaran }\end{array}$ \\
\hline & Kharaneh IV Phase B & & $\mathrm{X}$ & $\begin{array}{l}\text { Obliquely truncated and backed } \\
\text { bladelets with fine retouch }\end{array}$ & Kebaran \\
\hline & Jilat 6 Lower Phase & $X$ & & $\begin{array}{l}\text { Narrow, finely made, curved \& pointed, } \\
\text { arched backed bladelets }\end{array}$ & Nebekian \\
\hline & Jilat 6 Middle Phase & $X$ & & $\begin{array}{l}\text { Robust La Mouillah points, double- } \\
\text { truncated backed bladelets \& Qalkhan } \\
\text { points }\end{array}$ & Qalkhan \\
\hline & Uwaynid 14 Lower \& Upper phases & $X$ & & $\begin{array}{l}\text { Narrow, finely made arched-backed, } \\
\text { curved \& pointed bladelets; upper phase } \\
\text { with La Mouillah points and double } \\
\text { truncated and backed bladelets }\end{array}$ & Nebekian \\
\hline & Uwaynid 18 Upper Phase & $X$ & & $\begin{array}{l}\text { Narrow, finely made, curved \& pointed, } \\
\text { arched-backed bladelets }\end{array}$ & Nebekian \\
\hline & Azraq 32 & $X$ & & Large, asymmetrical triangles & Qalkhan (?) \\
\hline & ‘Ayn Qasiyya Area A/B & & $\mathrm{X}$ & $\begin{array}{l}\text { Obliquely truncated and backed } \\
\text { bladelets }\end{array}$ & Kebaran \\
\hline & 'Ayn Qasiyya Area D & $x$ & & $\begin{array}{l}\text { Arched-backed \& pointed bladelets, rare } \\
\text { Qalkhan and La Mouillah points }\end{array}$ & Nebekian \\
\hline & Kharaneh IV Phase C & & $\mathrm{X}$ & $\begin{array}{l}\text { Backed and truncated bladelets with } \\
\text { abrupt retouch }\end{array}$ & Nizzanian (?) \\
\hline & Jilat 6 Upper Phase & $x$ & & $\begin{array}{l}\text { Asymmetric and symmetric triangles; } \\
\text { microgravette points, and curved, } \\
\text { pointed and arched-backed pieces }\end{array}$ & Nizzanian \\
\hline & Azraq 17 Trench 1 & $\mathrm{X}$ & & $\begin{array}{l}\text { Truncated bladelets, triangles and } \\
\text { lunates }\end{array}$ & Nizzanian \\
\hline \multirow{7}{*}{ 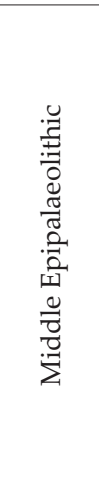 } & Jilat 22 Lower \& Middle phases & $x$ & & 'Tanged knife' common in middle phase & 'Tanged knives' \\
\hline & Jilat 22 Upper phase & $\mathrm{x}$ & & $\begin{array}{l}\text { Backed bladelet fragments, trapeze- } \\
\text { rectangles, La Mouillah points, triangles } \\
\text { and lunates }\end{array}$ & Mushabian (?) \\
\hline & Jilat 8 & $\mathrm{x}$ & & $\begin{array}{l}\text { Trapeze/rectangles, La Mouillah points, } \\
\text { curved, arched-backed bladelets }\end{array}$ & Mushabian (?) \\
\hline & Jilat 10 & & $x$ & $\begin{array}{l}\text { Few microliths, mainly retouched blades, } \\
\text { burins and truncations }\end{array}$ & 'Blade dominated' \\
\hline & Kharaneh IV Phase D & & $x$ & $\begin{array}{l}\text { Large trapeze-rectangles with variable } \\
\text { distal and proximal retouch }\end{array}$ & Geometric Kebaran \\
\hline & AWS 48 & & $\mathrm{X}$ & Trapeze-rectangles & Geometric Kebaran \\
\hline & Jilat 28 & & $\mathrm{X}$ & $\begin{array}{l}\text { Rare, large trapeze-rectangles with } \\
\text { variable distal and proximal retouch }\end{array}$ & Geometric Kebaran \\
\hline \multirow{6}{*}{ 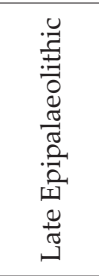 } & Azraq 18 & $X$ & & $\begin{array}{l}\text { Helwan lunates, and some abrupt/ } \\
\text { bipolar lunates }\end{array}$ & Natufian \\
\hline & Bawabah (Bawwab al-Ghazal) & $?$ & $?$ & Predominantly abrupt/bipolar lunates & Natufian \\
\hline & Khallat Anaza & $x$ & & Predominantly abrupt/bipolar lunates & Natufian \\
\hline & Mugharet el-Jawa & & $\mathrm{X}$ & Predominantly abrupt/bipolar lunates & Natufian \\
\hline & Shubayqa I & & $x$ & Predominantly abrupt/bipolar lunates & Natufian \\
\hline & Jebel Subhi & $X$ & & Predominantly abrupt/bipolar lunates & Natufian \\
\hline
\end{tabular}

rally but also spatially patterned. The lithic industries of Early Epipalaeolithic phases in the Wadi el-Jilat and Wadi Uwaynid fall within the spectrum of the Nebekian industry found within the eastern Levant (Goring-Morris 1995; Goring-Morris \& Belfer-Cohen 1998; Henry 1989; 1995; Olszewski 2001; 2006). Kha- raneh IV, on the other hand, only contains assemblages of a Kebaran affinity. 'Ayn Qasiyya is the only site in the Azraq Basin, and apparently in the whole of the southern Levant, which has produced both Nebekian and Kebaran inventories (Richter et al. 2010a; Richter in press). Stratigraphically later assemblages (Jilat 6 
Natufian
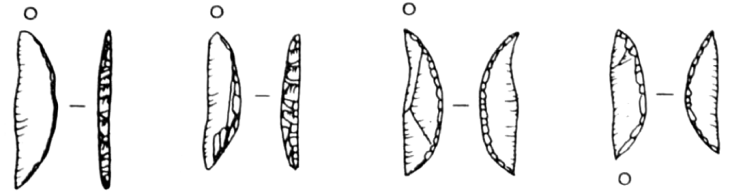

Azraq 18
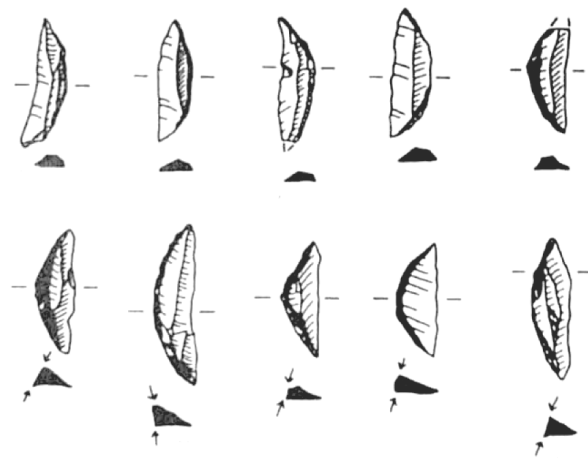

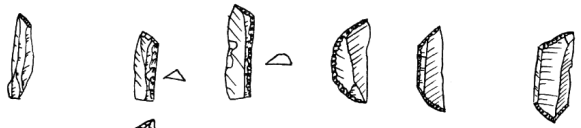

Khallat Anaza

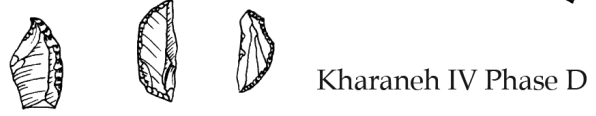

1) 通 D
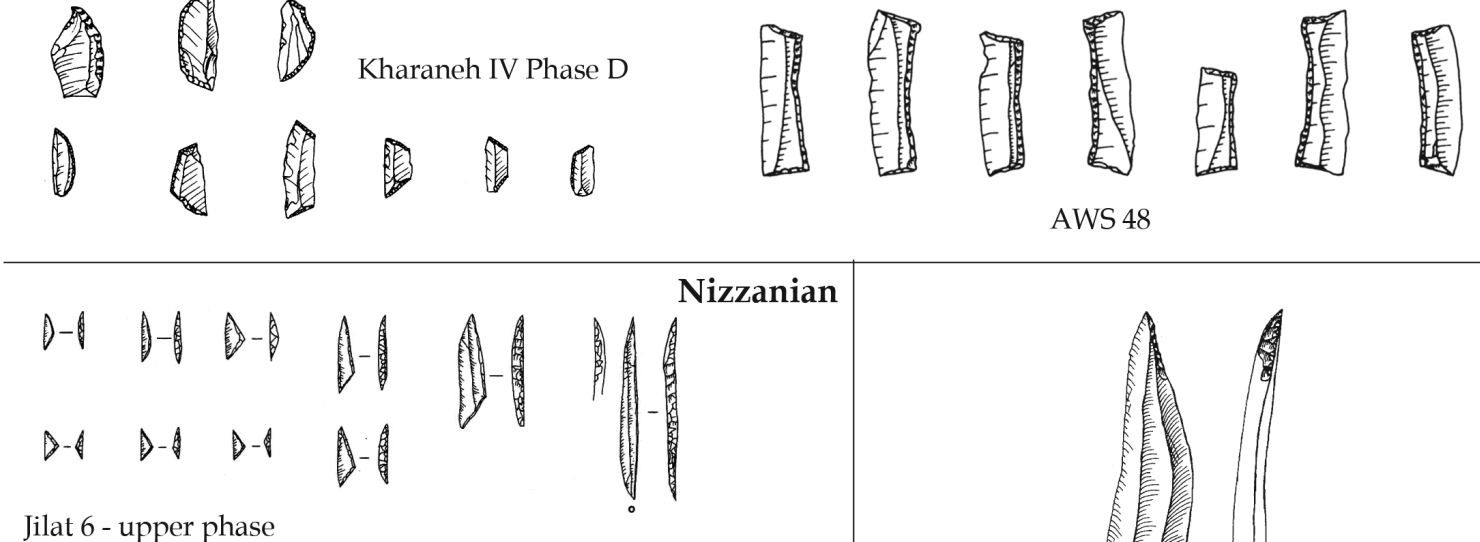

Jilat 6 - upper phase

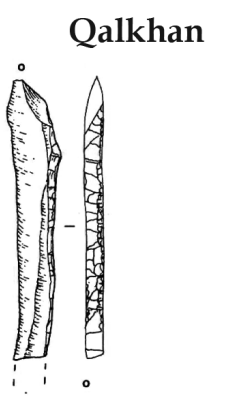

Jilat 6 - middle phase

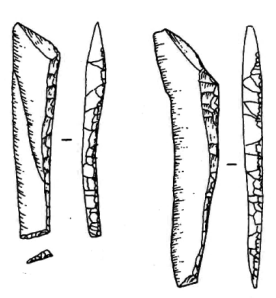

Nebekian

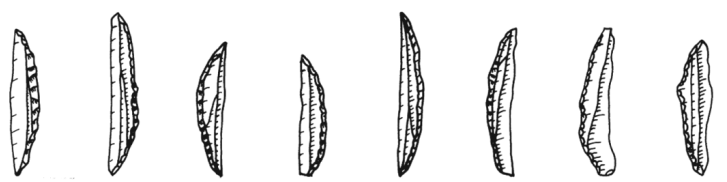

Ayn Qasiyya Area D
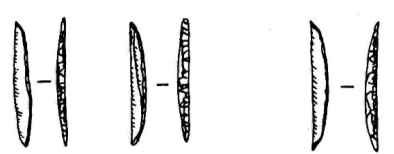

Jilat 6 - lower phase

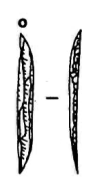

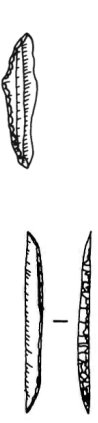

-
Jilat 22 Phase C
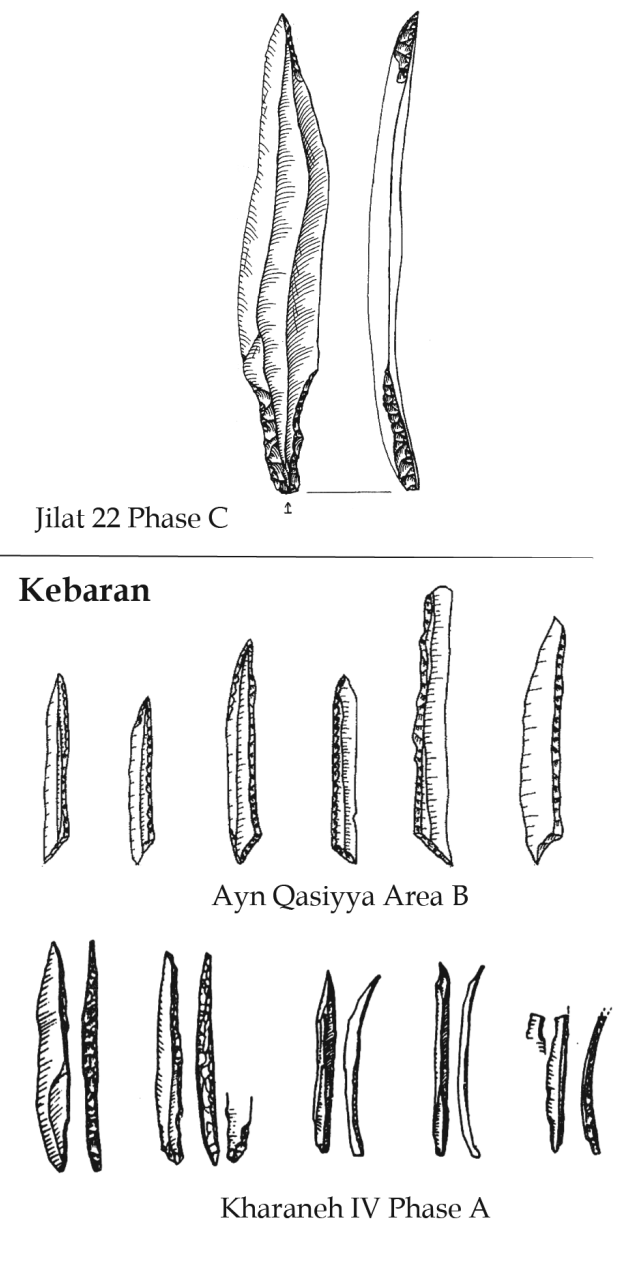

Figure 3. Diagnostic chipped-stone tools from Epipalaeolithic sites in the Azraq Basin (not to scale; compiled from Byrd 1988; Garrard \& Byrd 1992; Muheisen 1988b; Garrard 1991; Betts 1998). 
upper phase, Kharaneh IV Phase C, Azraq 17 Trench 1), show superficial similarities, yet further studies are in progress - particularly on the Kharaneh IV assemblage - to verify their exact commonalities. During the subsequent Middle Epipalaeolithic, sites that can be broadly considered to belong to the Geometric Kebaran can be found in the oasis at AWS 48 (Richter in press), at Kharaneh IV Phase D (Muheisen 1988a,c) and Jilat 28 (Garrard \& Byrd in prep.). The Middle Epipalaeolithic assemblages from the Wadi el-Jilat, on the other hand, show a more diverse range of microliths with the addition of a previously unseen tool type - the Jilat knife (Garrard \& Byrd 1992). During the late Epipalaeolithic, lithic inventories are more directly comparable across the Azraq Basin, and can all be broadly identified with the Natufian (Betts 1991; 1998; Garrard 1991). Considering the technological and typological variability of these assemblages, their spatial distribution in the region, and change in these factors over time we argue that these characteristics allow us to trace interaction between different communities of final Pleistocene hunter-gatherers.

Tracing social interaction on the basis of chippedstone artefacts is of course a tricky business. There has been considerable debate amongst prehistorians working in the Epipalaeolithic of the Levant, as elsewhere, about the interpretation of variability in lithic artefact industries (Bar-Yosef 1991; Barton \& Neeley 1996; Clark 1996; Fellner 1995b; Goring-Morris 1996; Henry 1995; Kaufman 1995; Neeley \& Barton 1994; Olszewski 2006; Phillips 1996). The technological and corresponding spatial patterns identified in the Azraq Basin are interesting since they reflect wider spatial arrangements of lithic industries during the Epipalaeolithic. During the Early Epipalaeolithic, Kebaran assemblages (lacking the microburin technique) are found predominantly along the Mediterranean coastal plain and in the central Rift Valley, extending into the Beqaa' Valley to the north (Bar-Yosef 1981; 1987; 1989; Fellner 1995a; Goring-Morris 1995; Goring-Morris \& Belfer-Cohen 1998; Hours 1992; Schyle 1996). Largely contemporary Nebekian inventories are predominantly found in the eastern, more arid Levant, stretching from southern Jordan all the way into central Syria (Byrd 1994; 1998; Goring-Morris 1995; Goring-Morris \& Belfer-Cohen 1998; GoringMorris et al. 2009; Henry 1995; Olszewski 2001; 2006; Rust 1950; Stutz \& Estabrook 2004; Schyle 1996). From the Nizzanian onwards, however, there appears to be somewhat less spatial differentiation. Nizzanian sites occur across the southern Levant in diverse ecological settings, including the arid zones of the Negev/ Sinai and the Azraq Basin, as well as the coastal plain
(Goring-Morris 1995). The Geometric Kebaran is also a pan-Levantine entity, although Henry (1989) has suggested some internal variation based primarily on the composition of major tool groups. Localized Middle Epipalaeolithic industries exist and the assemblages from Jilat 8 and Jilat 22 upper phase have been associated with the Mushabian industry (Garrard \& Byrd in prep.; Goring-Morris 1995; Goring-Morris \& Belfer-Cohen 1998; Goring-Morris 1987). The Late Epipalaeolithic sites in the Azraq Basin fall under the pan-Levantine phenomenon of the Natufian.

Most scholars agree that this technological variability, recognized from its spatial and temporal patterning, is in one way or another related to past 'social groups' (Clark 1996; Fellner 1995b; GoringMorris 1995; 1996; Henry 1996; Kaufman 1995; Phillips 1996). Some have suggested that these social groups should be thought of as groups based on kinship and that the lithic inventories can therefore be taken to reflect ethnic communities (Bar-Yosef 1991, 381-4; Henry 1989, 170-75; 1995, 420). Beyond ethnographic analogies there is unfortunately little direct evidence to verify independently this interpretation. It is probably most appropriate to consider the shared technological and typological characteristics between lithic assemblages to be related to past 'traditions' in the very broadest sense of the term. Although it is clearly difficult to avoid the normative, primordial connotations of this term in its most cultural-historical sense (Hodder 1982; 1986; Jones 1997; Shanks \& Tilley 1987, 80-82), tradition does not necessarily have to imply a concept of static 'mental templates' of manufacturing procedures and tool forms. Instead, they can be considered in a more reciprocal manner, being situated between the actions of individuals and social structures as material expressions of the process of structuration between these two, interdependent poles (Barrett 2001; Barrett \& Fewster 1999; Bourdieu 1977; 1990; Dobres 2000; Giddens 1979; 1984; Hodder 1986; Ingold 2000; Lemonnier 1989; 1990; 1992; Pfaffenberger 1992; Shanks \& Tilley 1987). In other words, they reflect habitual yet dynamic, learned gestures and techniques mediated within social structures and relationships (Mauss 1935). On the basis of the characteristics of the chipped-stone artefact inventories, their technological variability and spatial patterning, we are able to pick up elements of practical knowledge shared between members of a community. Such a community can be defined through these shared practices, gestures, knowledge and material culture that are propagated through learning and socialization within the community so that they are 
reproduced again and again over time (Dobres 2000, 129-35; Lave \& Wenger 1991; Minar 2001; Sassaman \& Rudolphi 2001; Wenger 1998).

On this basis, we argue that the spatial patterning of lithic assemblages does reflect the presence of different communities in the Azraq Basin, defined by their shared knowledge and 'histories of learning' (Wenger 1998). Excavations at 'Ayn Qasiyya seem to show that the Nebekian and Kebaran lithic industries in the Azraq Basin can be considered to be contemporary (Richter 2009; Richter et al. 2007; 2010a). This differentiation in tool kits continues into the Middle Epipalaeolithic in the Azraq Basin. While Nizzanian toolkits are present at three sites, they are subtly different in microlith form and application of the microburin technique. In the Middle Epipalaeolithic, Geometric Kebaran sites are known from AWS 48, Kharaneh IV and Wadi Jilat 28. However, while they can be broadly identified with the Geometric Kebaran, they differ in tool form composition from classic Geometric Kebaran assemblages and from each other. While both lack the microburin technique, trapeze-rectangles at Kharaneh IV are far more diverse and the toolkit in general is more varied (Muheisen 1988a,c; Muheisen \& Wada 1995). But in comparison to the Middle Epipalaeolithic sites such as Jilat 22 lower and middle phases, and Jilat 10 (Byrd 1988; Byrd \& Garrard 1989; Garrard \& Byrd 1992; Garrard et al. 1994a), which do not readily resemble any current lithic industry label, they nevertheless represent a coherent group of assemblages. The distinction between inventories and their spatial distribution is a pattern that is maintained into the Middle Epipalaeolithic. While Late Epipalaeolithic industries are known from less thoroughly explored sites and generally represent much smaller samples, they can all be assigned to the Natufian (Betts 1991; 1998; Garrard 1991). It appears that by the Late Epipalaeolithic a coherent technological lithic repertoire had emerged in the Azraq Basin, which is akin to other assemblages throughout the Levant. While the appearance of the Natufian suggests the spread of either communities or ideas coming in from outside the region (i.e. southern Jordan or the Mediterranean littoral: Bar-Yosef 1998; Bar-Yosef \& Belfer-Cohen 2000), it is interesting to note that there appears to be a blending of traditions in the Azraq Basin beginning in the Middle Epipalaeolithic. Certain technological elements, e.g. the microburin technique, begin to appear at other sites, and distinct tool types also become more shared between sites. This may be taken as an indicator for the increase in interaction between groups and the sharing of practical knowledge and ideas between different communities.
The spatial patterns exhibited by Epipalaeolithic lithic industries in the Azraq Basin are considered here as representing hunter-gatherer knowledge and skills, taught and learnt within particular social communities. We necessarily have to draw on some broad assumptions in this argument in order to interpret these patterns. The time period under discussion comprises $c$. 10,000 years and there is plenty of scope for diachronic and idiosyncratic change and variability. Current chronological data from Azraq do not yet provide us with a finer resolution to demonstrate contemporaneity of occupations or lithic assemblages (and perhaps never will). Broadly speaking, we consider many of the industries discussed here to be at least partly contemporary and at least in one way or another related to differences in people's practical knowledge and technological intentionality. By focusing not on the identification of archaeological patterns with ethnic or cultural dimensions (modern distinctions whose existence are far from clear in prehistory), but by insisting on the gestured politics and learned habits of persons situated within social structures we aim to highlight one element of organization and interaction in the Final Pleistocene of the Azraq Basin. We would emphasize that this is in line with the way in which many other scholars have discussed variability in the lithic industries of the Final Pleistocene (Bar-Yosef 1991; Byrd 1994; 1998; Goring-Morris 1995; Goring-Morris \& Belfer-Cohen 1998; Goring-Morris et al. 2009; Henry 1989; 1995; Stutz \& Estabrook 2004).

\section{Shell beads}

While lithic artefact assemblages, spatial distributions and their association with broader lithic industries establish a basis on which to consider interaction, other material culture can be recruited to trace interactions between these socio-cultural entities. At the same time, these other materials provide further evidence that we are indeed dealing with distinct communities who are engaged in the exchange of objects. Marine shells have been reported from a number of Epipalaeolithic sites in the Levant, both in the Azraq Basin and elsewhere (Bar-Yosef Mayer 1989; 1991; 2005; Goring-Morris 1989; Reese 1991; 1995). Bar-Yosef Mayer (2005) has documented transport of Mediterranean sea shells over distances of $280 \mathrm{~km}$ in the Sinai, while Goring-Morris (1989) has described the exchange of marine shells in the Sinai and Negev. Reese $(1991 ; 1995)$ discussed the use and transport of marine shells at a number of sites throughout the Levant, including the Hisma sites of southern Jordan, 


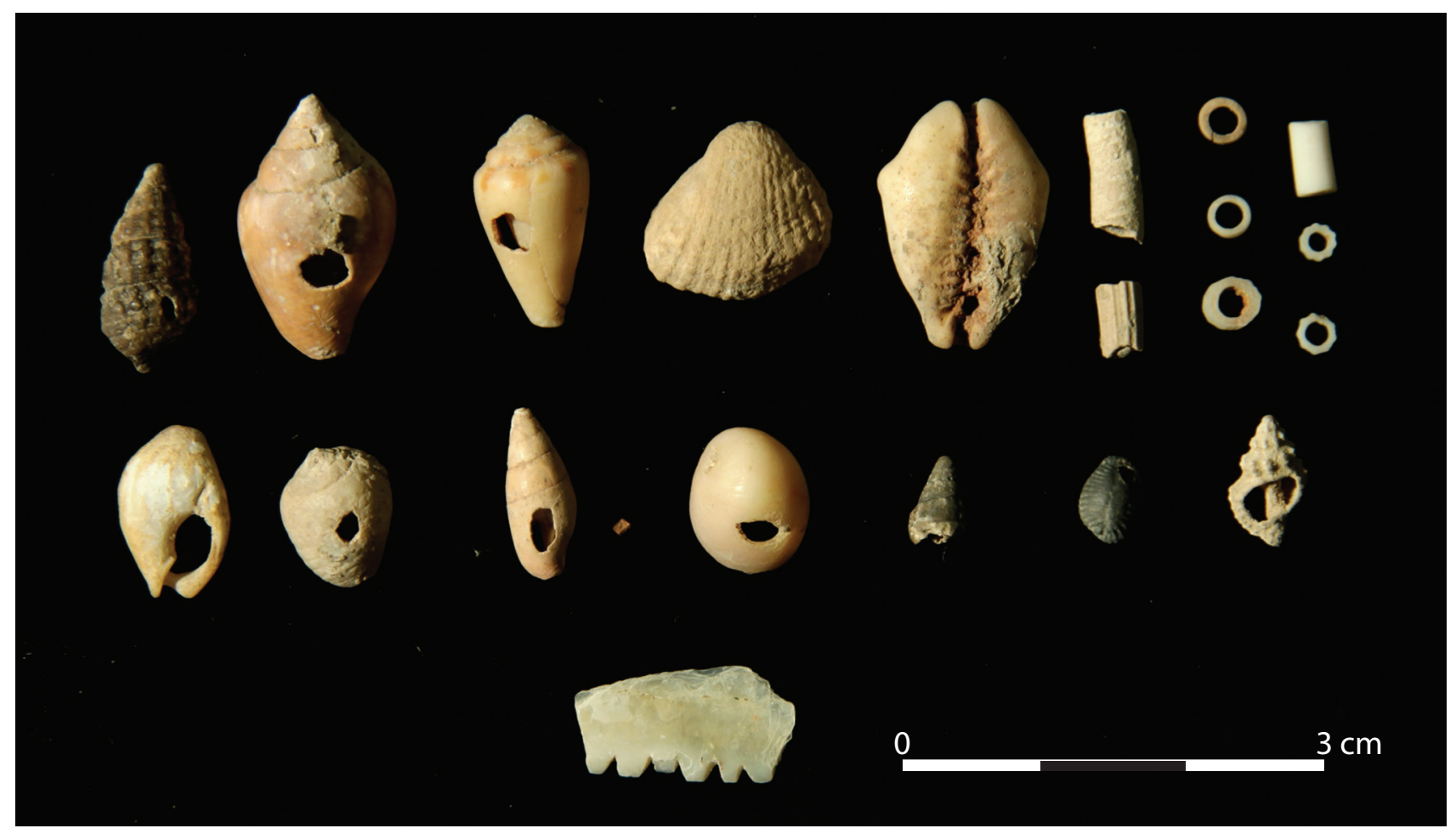

Figure 4. Pierced marine shells from Kharaneh IV Area A.

where Red Sea species dominate and only a few Mediterranean shells are present.

In the Azraq Basin marine shells have been found at Jilat 6, 8, 10, 22, Uwaynid 18 and Azraq 17, 18, 32, (Garrard et al. 1994a; Reese 1991) and Kharaneh IV (Allcock 2009; Muheisen 1983; 1988a,c; Reese 1991; Fig. 4). Piercing on a large number of these shells strongly suggests that they were probably used as beads or pendants. Reese (1991) identified the material from the Jilat, Uwaynid and Azraq sites to genus-level and showed that Dentalium, Nassarius, Pyrene, Ancilla, Cerastoderma, Columbella, Cerithium and Nerita shells are present at various of the above-mentioned sites (Table 3). While Dentalium, Nassarius, Pyrene and Columbella genera occur both in the Red Sea and the Mediterranean, Ancilla and Nerita are native to the Red Sea only, and Cerastoderma are found only in the Mediterranean. Recent studies of marine and land shells from the renewed excavations at Kharaneh IV (where most identifications were made to specieslevel) shows that Nerita sanguinolenta (native to the Red Sea) and Mitrella scripta (native to the Mediterranean) are the most common species (Allcock 2009; Table 4). Antalis sp. is also common at Kharaneh IV, but because these tube-shaped shells were cut into short, ring-shaped segments, the number of individual beads at the site does not provide a good indicator of their relative frequency. Nerita sanguinolenta are present in small numbers from the Early Epipalaeolithic levels onwards, but increase in frequency toward the Middle Epipalaeolithic (Phase D). Columbella rustica and Conus meditteraneus on the other hand are present in relatively larger numbers from the Early Epipalaeolithic levels onwards and decrease in abundance towards the Middle Epipalaeolithic.

Bearing in mind that the lithic industries common to both Jilat 6 and Uwaynid 14/18 can be considered to be very similar to those of southern Jordan and that the lithic assemblages of Kharaneh IV are related to those of the western, Mediterranean Levant, it is intriguing to note that Jilat 6 produced some shells of Mediterranean origin, and Kharaneh IV Red Sea shells (Allcock 2009; Reese 1991; Tables 3 \& 4). At Jilat 6, a majority of the sea shells are associated with the last phase of occupation at the site, rather than the earlier levels (Garrard et al. 1994a). Nevertheless, a few sea shells were also evident in the lower strata. An interesting tendency begins to emerge here: some Mediterranean Sea shells have been found on sites that are associated with an otherwise exclusively east Levantine lithic industry (whose distribution extends south though the steppe towards the Red Sea). At the same time some Red Sea shells have been found on sites associated with 
Interaction before Agriculture: Exchanging Material and Sharing Knowledge

Table 3. Absolute and percentile frequencies of marine shells from Early, Middle and Late Epipalaeolithic sites investigated as part of the Azraq Basin Early Prehistory Project. (Data compiled by David Reese.)

\begin{tabular}{|c|c|c|c|c|c|c|c|c|c|c|c|c|c|}
\hline Species & $\begin{array}{l}\text { Uwaynid } \\
18 \text { upper }\end{array}$ & $\begin{array}{l}\text { Uwaynid } \\
18 \text { lower }\end{array}$ & $\begin{array}{l}\text { Jilat } 6 \\
\text { surface }\end{array}$ & $\begin{array}{l}\text { Jilat } 6 \\
\text { upper }\end{array}$ & $\begin{array}{c}\text { Jilat } 6 \\
\text { middle }\end{array}$ & $\begin{array}{l}\text { Jilat } 22 \\
\text { surface }\end{array}$ & $\begin{array}{c}\text { Jilat } 22 \\
\text { upper }\end{array}$ & $\begin{array}{l}\text { Jilat } 22 \\
\text { middle }\end{array}$ & Jilat 10 & \begin{tabular}{|l|l} 
Jilat 8 \\
\end{tabular} & $\begin{array}{c}\text { Azraq } \\
17 \\
\text { Trench } 2 \\
\end{array}$ & $\begin{array}{c}\text { Azraq } \\
32\end{array}$ & $\begin{array}{c}\text { Azraq } \\
18\end{array}$ \\
\hline Dentalium $^{\mathrm{a}}$ & 6 & 5 & 0 & 52 & 1 & 2 & 7 & 2 & 5 & 7 & 4 & 1 & 24 \\
\hline Nassarius $^{\mathrm{a}}$ & 0 & 0 & 1 & 5 & 1 & 0 & 0 & 0 & 0 & 0 & 0 & 0 & 0 \\
\hline Pyrene $^{\mathrm{a}}$ & 0 & 0 & 0 & 24 & 0 & 0 & 8 & 0 & 4 & 2 & 0 & 0 & 0 \\
\hline Ancilla $^{\mathrm{b}}$ & 0 & 0 & 1 & 4 & 0 & 0 & 0 & 0 & 0 & 0 & 0 & 0 & 0 \\
\hline $\begin{array}{l}\text { Unidentified } \\
\text { gastropod }\end{array}$ & 0 & 0 & 0 & 4 & 1 & 1 & 2 & 0 & 1 & 0 & 0 & 0 & 0 \\
\hline Cerastodermac & 0 & 0 & 0 & 5 & 0 & 0 & 1 & 0 & 0 & 0 & 0 & 0 & 1 \\
\hline Columbella $^{\mathrm{a}}$ & 0 & 0 & 0 & 0 & 0 & 1 & 1 & 1 & 0 & 1 & 0 & 0 & 0 \\
\hline Cerithium $^{\mathrm{a}}$ & 0 & 0 & 0 & 0 & 0 & 0 & 1 & 0 & 0 & 0 & 0 & 0 & 0 \\
\hline Nerita $^{\mathrm{b}}$ & 0 & 0 & 0 & 0 & 0 & 0 & 0 & 0 & 7 & 0 & 0 & 0 & 0 \\
\hline \multirow[t]{2}{*}{ Total } & 6 & 5 & 2 & 94 & 3 & 4 & 20 & 3 & 17 & 10 & 4 & 1 & 25 \\
\hline & $\%$ & $\%$ & $\%$ & $\%$ & $\%$ & $\%$ & $\%$ & $\%$ & $\%$ & $\%$ & $\%$ & $\%$ & $\%$ \\
\hline Dentalium $^{\mathrm{a}}$ & 100.00 & 100.00 & 0.00 & 55.32 & 33.33 & 50.00 & 35.00 & 66.67 & 29.41 & 70.00 & 100.00 & 100.00 & 96.00 \\
\hline Nassarius $^{\mathrm{a}}$ & 0.00 & 0.00 & 50.00 & 5.32 & 33.33 & 0.00 & 0.00 & 0.00 & 0.00 & 0.00 & 0.00 & 0.00 & 0.00 \\
\hline Pyrene $^{\mathrm{a}}$ & 0.00 & 0.00 & 0.00 & 25.53 & 0.00 & 0.00 & 40.00 & 0.00 & 23.53 & 20.00 & 0.00 & 0.00 & 0.00 \\
\hline Ancilla $^{\mathrm{b}}$ & 0.00 & 0.00 & 50.00 & 4.26 & 0.00 & 0.00 & 0.00 & 0.00 & 0.00 & 0.00 & 0.00 & 0.00 & 0.00 \\
\hline $\begin{array}{l}\text { Unidentified } \\
\text { gastropod }\end{array}$ & 0.00 & 0.00 & 0.00 & 4.26 & 33.33 & 25.00 & 10.00 & 0.00 & 5.88 & 0.00 & 0.00 & 0.00 & 0.00 \\
\hline Cerastodermac & 0.00 & 0.00 & 0.00 & 5.32 & 0.00 & 0.00 & 5.00 & 0.00 & 0.00 & 0.00 & 0.00 & 0.00 & 4.00 \\
\hline Columbella $a^{\mathrm{a}}$ & 0.00 & 0.00 & 0.00 & 0.00 & 0.00 & 25.00 & 5.00 & 33.33 & 0.00 & 10.00 & 0.00 & 0.00 & 0.00 \\
\hline Cerithium $^{\mathrm{a}}$ & 0.00 & 0.00 & 0.00 & 0.00 & 0.00 & 0.00 & 5.00 & 0.00 & 0.00 & 0.00 & 0.00 & 0.00 & 0.00 \\
\hline Nerita $^{\mathrm{b}}$ & 0.00 & 0.00 & 0.00 & 0.00 & 0.00 & 0.00 & 0.00 & 0.00 & 41.18 & 0.00 & 0.00 & 0.00 & 0.00 \\
\hline Total & 100.00 & 100.00 & 100.00 & 100.00 & 100.00 & 100.00 & 100.00 & 100.00 & 100.00 & 100.00 & 100.00 & 100.00 & 100.00 \\
\hline
\end{tabular}

Table 4. Marine shells from the Early and Middle Epipalaeolithic phases at Kharaneh IV (Allcock 2009).

\begin{tabular}{|c|c|c|c|c|}
\hline \multirow[b]{2}{*}{ Species } & \multicolumn{2}{|c|}{ Kharaneh IV - Early Epipalaeolithic } & \multicolumn{2}{|c|}{ Kharaneh IV - Middle Epipalaeolithic } \\
\hline & No. & $\%$ & No. & $\%$ \\
\hline Columbella rusticac & 47 & 19.42 & 16 & 2.02 \\
\hline Trivia monachac & 0 & 0.00 & 1 & 0.13 \\
\hline Cantharus pictus ${ }^{\mathrm{C}}$ & 1 & 0.41 & 0 & 0.00 \\
\hline Nerita sanguinolenta ${ }^{\mathrm{b}}$ & 8 & 3.31 & 139 & 17.53 \\
\hline Mitrella scriptac & 86 & 35.54 & 145 & 18.28 \\
\hline Cerithium scabridum 1 & 1 & 0.41 & 0 & 0.00 \\
\hline Conus mediterraneus ${ }^{\mathrm{c}}$ & 43 & 17.77 & 3 & 0.38 \\
\hline Nassarius gibbosulus ${ }^{\mathrm{c}}$ & 0 & 0.00 & 2 & 0.25 \\
\hline Euplica turturina ${ }^{\mathrm{d}}$ & 3 & 1.24 & 8 & 1.01 \\
\hline Turritella $^{\mathrm{a}}$ & 2 & 0.83 & 1 & 0.13 \\
\hline Nassarius edwardsic & 0 & 0.00 & 1 & 0.13 \\
\hline Cypraea erosa nebrites ${ }^{b}$ & 4 & 1.65 & 0 & 0.00 \\
\hline Pinctada radiata ${ }^{\mathrm{a}}$ & 7 & 2.89 & 3 & 0.38 \\
\hline Cerastoderma glaucum ${ }^{\mathrm{a}}$ & 3 & 1.24 & 12 & 1.51 \\
\hline Antalis sp. ${ }^{a}$ (Dentalium) & 25 & 10.33 & 417 & 52.59 \\
\hline Unidentifiable & 12 & 4.96 & 45 & 5.67 \\
\hline Total & 242 & 100.00 & 793 & 100.00 \\
\hline
\end{tabular}


a western Levantine lithic industry (whose distribution extends to the Mediterranean). Certain genera, including Nassarius and Columbella, occur in both the Mediterranean and Red Sea, and could thus indicate connections to either sea shore. What is critical here, however, is that we can link the origins of these sea shells with the spatial distribution of lithic assemblages in the southern Levant, especially during the Early Epipalaeolithic. In the Azraq Basin, sites that have lithic assemblages associated with practically exclusive east or west Levantine distributions contain sea shells that originate from both the Red Sea and the Mediterranean Sea. Most of the marine shells from the Wadi el-Jilat sites cannot be identified to have come from either the Red Sea or the Mediterranean. Those shells whose origin can be determined represent only a small sample and are evenly divided between the two. The case for the assemblage from Kharaneh IV is, however, somewhat stronger, since this site has produced a much larger sample.

The presence of both Mediterranean and Red Sea shells at sites in the Azraq Basin indicates the wide-ranging connections between this and adjacent regions (Allcock 2009; Reese 1991). It seems evident that the Azraq Basin was linked into a wider network of movement and material exchange throughout the southern Levant. It is not impossible to assume that the collection of sea shells occurred when groups were seasonally resident along the Mediterranean or Red Sea shores and that they brought sea shells with them to the Azraq Basin as part of seasonal migrations and movements. Hunter-gatherer group territory sizes have previously been estimated to lie around 260-770 $\mathrm{km}^{2}$ (Henry 1989, 174; see also Binford 2001, table 8.04, 270-75), based on ethnographical parallels. But hunter-gatherers rarely travel such distances in a linear fashion, as the Azraq Basin case would imply with movement to and from Azraq to either the Red Sea or Mediterranean. It seems therefore more likely that shells were exchanged along inter-regional networks between different groups inhabiting more localized territories, by which means they arrived in the Azraq Basin where they were then exchanged between groups who had established different links. We cannot be absolutely certain whether exchange only occurred in the Azraq Basin. Red and Mediterranean Sea shells may well have been exchanged outside the Azraq Basin and only brought to the region afterwards. However, it is fair to point out that the Azraq Basin is the only region in which the pattern of Red and Mediterranean Sea shell distribution versus the patterned distribution of distinct lithic industries is evident in this form, at least during the Early Epipalaeolithic.
The precise nature of interactions during which shell beads were exchanged remains elusive. However, two observations may help us to better understand their importance to Epipalaeolithic communities. One, it is probably fair to assume that these were exotic items, having been brought to Azraq over considerable distances $(290 \mathrm{~km}$ to the Red Sea and 170 $\mathrm{km}$ to the Mediterranean Sea). It suggests that they held sufficient value to people to have been taken on these long trips - perhaps even specifically with the intention of exchange in mind. The second important observation here is that virtually all the shells were pierced, suggesting that they were hung as pendants, strung as part of necklaces, headsets, or other adornments of clothes or objects (Allcock 2009). Many were also stained with ochre. Indeed, their meaning and assigned value may have been closely related to their importance in these instances of the construction of body politics (Entwistle 2000; Joyce 2005; Meskell 1999; Yates 1993; Wright \& Garrard 2003), although of course other uses are also possible (counting aides, game pieces, etc.).

This exchange in shells can be considered to be a material manifestation of the establishment of social ties, interactions and relationships between groups. Marcel Mauss famously described exchange as a 'total social phenomenon' (Mauss 1935, 3). Therefore, as shells were exchanged, ideas and knowledge were likewise passed on, resulting in a blending of cultural differences. Obtaining and trading shells may have also been an important factor in enhancing individual and group status, and may have played a role in wider social rituals, such as initiation rites, marriages or annual, seasonal meetings between groups. It is very possible that marine shells played a symbolic role in some, or several, of these practices and that they helped to affirm ties and relations within and between communities.

These interactions may have been friendly, or not, but in either case, it could have resulted in the borrowing, taking or exchanging of ideas and objects, of which shell and stone tools (if not microliths themselves, then at least the idea of what shapes to make them) were two examples. There is some indication that these interactions and exchanges may have intensified toward the Middle Epipalaeolithic, as seems to be suggested by the relative increase in marine shell in the region. In any case, the likely reciprocity underlying these exchanges (Gregory 1994), was probably related to much wider underlying social practices, which incorporated understandings regarding wealth and commodity, rules for exchange, cosmology and ideology. It reflects a complex web of interaction 
Interaction before Agriculture: Exchanging Material and Sharing Knowledge

which, although only preserved in the most ephemeral manner in the archaeological record, indicates a regional and pan-regional network of relationship and ties between communities. What is most evident, is the inter-relatedness of people and localities, manifested in the shared acquisition and use of marine shell.

\section{Ground-stone tools}

Ground-stone tool raw-material procurement and distribution can be considered an additional, if more oblique, indicator for interaction in the Azraq Basin. Ground stone is rare at most Early and Middle Epipalaeolithic sites, with a notable increase in presence during the Late Epipalaeolithic Natufian (Peterson 1999; Wright 1991; 1992a,b; 1994). In the Azraq Basin ground-stone tools were found in the Early Epipalaeolithic levels at Azraq 17, Uwaynid 18, Jilat 6 (Wright 1991; 1992b), Kharaneh IV (Muheisen 1983; 1988a,b), as well as in the Middle Epipalaeolithic deposits at Jilat 8, 22 (Wright 1991; 1992b) and Kharaneh IV (Muheisen 1983; 1988a,b,c). Portable ground-stone and bedrock mortars are known from virtually all major Late Epipalaeolithic sites in the basin (Betts 1991; 1998; Garrard 1991). Basalt was the preferred raw material for the production of these tools. Natural basalts are widespread throughout the northern and eastern Azraq Basin, where they form extensive boulder fields and outcrops (Bender 1974). While basalt outcrops in close proximity to some sites (Uwaynid 14 and 18, Azraq 17, and most of the Late Epipalaeolithic sites), it is some distance from the sites in the Wadi el-Jilat (c. $45 \mathrm{~km}$ ) and Kharaneh IV (c. $25 \mathrm{~km}$ ). There is therefore unequivocal evidence for the transportation of either finished tools or raw material for tool production to these sites. The exact provenance of basalt tools from these sites cannot, at present, be demonstrated due to a lack of sourcing studies. It should be noted that there are also basalt sources in the west Jordanian highlands, but they are at greater distances than those in the north and east Azraq Basin (the Wadi el-Mujib source is $c .60 \mathrm{~km}$ west of Wadi el-Jilat and much further from the other sites being discussed). Given that sites with very comparable chipped-stone inventories are known from the Azraq Basin, and since these are part of a regional settlement pattern, it seems more straightforward to think of intra-regional, Azraqspecific networks of material procurement and transportation. The movement of materials consequently implies the movement of people through the Azraq landscape. While the discovery of basalt ground-stone objects is not a clear-cut case of exchange, it nevertheless heightens the possibility of people meeting and interacting at various localities. Source locations for suitable raw materials were part of the common knowledge of groups and access to these may have been regulated or restricted in certain ways. While moving through the landscape or extracting material at these sources people likely encountered other groups, which created the setting for interaction. But raw material extraction and transport are naturally not the only instances in which such opportunities for interaction could have arisen.

\section{Settlement patterns}

The current distribution and nature of Epipalaeolithic sites in the Azraq Basin, seems to suggest a hierarchical settlement pattern. Although our knowledge is necessarily limited due to the uneven survey coverage of the region, it is possible to see that the distribution and character of archaeological sites fits the expectations for a logistical settlement pattern (Binford 1980). The density of finds, thickness of deposits and, for this time period, enormous size, suggests that Kharaneh IV and Jilat 6 are agglomeration sites where large groups of people came together over the course of hundreds of years (c. 3000 years in the case of Kharaneh IV: see also Garrard \& Byrd 1992). These sites are associated with distinct lithic inventories (see above) and could be considered to have been occupied by groups with distinct technological and practical histories of learning. The spatial distribution of these sites highlights that agglomeration sites are found at some distance from the central oasis. Nearer to the oasis there are no known sites of comparable size during the Early or Middle Epipalaeolithic. It is possible that large sites are not found near the oasis because agglomeration sites were not needed in locales where wetland resources were available year-round. The migration of seasonal birds into the oasis may, however, have provided a seasonal incentive to use the oasis at particular times throughout the year. Sites with both Kebaran and Nebekian inventories (Uwaynid 14 and 18, 'Ayn Qasiyya), as well as a Geometric Kebaran site (AWS 48) and other potentially Early/Middle Epipalaeolithic sites (Azraq 17 Trench 1, Azraq 32) are known from within the oasis. The more dispersed settlement pattern near and in the oasis evident during Early and Middle Epipalaeolithic suggests that multiple groups exploited its resources and potentially shared the opportunities arising from the perennial water supply, game and plants available here. One of the recurrent questions in the study of the Epipalaeolithic of the Azraq Basin is why large sites such as Kharaneh IV and Jilat 6 were not established in the oasis itself. 
Since the oasis has been subjected to intensive survey, the lack of such sites cannot be attributed to a gap in research coverage. The oasis would have provided ideal conditions for such large settlements, with water, game and plants being very abundant. While it is possible that the oasis was unattractive for this type of settlement for other reasons, it is also possible that social mechanisms existed to mitigate human impact and over-exploitation of the oasis. Faunal evidence indicates that visits likely occurred on a seasonal basis during the Early and Middle Epipalaeolithic (Martin 1994; Richter et al. 2010a). If we accept that different kinds of social groups - however defined - drew on the oasis at particular points throughout the year shared the resources in this rich area, there is a high potential for interactions to have occurred. Of course, these interactions must not necessarily have been friendly. Rather than sharing resources, people may have competed over them, which could have involved conflict or violence. However, there is no direct evidence for one over the other, and peoples' engagement with each other is likely to have involved both at different points in time.

\section{Discussion}

We have discussed four related lines of evidence that provide some insight into interactions that occurred in the Azraq Basin during the final Pleistocene. Because of the spatially patterned distribution of lithic industries across the southern Levant and the traceable origins of certain shell beads from either the Mediterranean or the Red Sea, there is strong evidence for group interaction from at least 20,000 вP onwards. This interaction involved the exchange of sea shells, as well as the exchange of concepts, knowledge and ideas. An increase in interactions is likely suggested by the apparent increase in the amounts of sea shells at sites in the Azraq Basin, as well as by the 'blending' of lithic technological and typological traditions during the Middle Epipalaeolithic. It is only during the Natufian that a more homogeneous picture emerges as part of a wider pan-Levantine process. By this time the Azraq Basin formed part of a broader and perhaps differently connected cultural sphere.

The kind of 'exchange system' described above provides new insights into the long-supposed social interaction between final Pleistocene huntergatherer groups. That sea shells were transported and exchanged in the Epipalaeolithic Levant is not in itself a radically new finding (Bar-Yosef Mayer 1989; 2005). But the existence of such regional and pan-regional systems of interaction and exchange have previously not been documented in sufficient detail. How can we situate these observations before the background of the critical social, economic and cultural changes of the transition from hunting and gathering to agriculture and village life? Interaction has been seen as one of the hallmarks of the Late Epipalaeolithic and the early Neolithic in the Levant, so much so that it helped to define the Neolithic as a new era in human development and history. Various scholars have argued that due to this interaction new forms of cultural and economic knowledge and new ideas travelled between different communities, uniting them in a shared and common Neolithic way of life (Cauvin 1994; Watkins 2003; 2008; 2010). The emergence of the rich body of Neolithic symbolism has often been connected to this interaction, as has the spread of agriculture and domestic animals.

In the Azraq Basin, interaction amongst hunting and gathering communities can be traced to before 20,000 cal. вр. People interacted in manifold and sustained ways within the Azraq Basin and over 5000 to 6000 years before the emergence of the Late Epipalaeolithic Natufian. This interaction was not sporadic nor circumstantial; at Kharaneh IV the exchange of sea shells is documented in all occupational phases. This shows at the very least that the interaction evident in the Natufian and the Pre-Pottery Neolithic has a much older ancestry than currently recognized. It could even be argued that there is essentially no difference between the kind of exchange that took place in the earlier Epipalaeolithic and the Late Epipalaeolithic and Neolithic. While the kind of objects and ideas, and likely the socio-cultural context as well, were undoubtedly different, it seems inappropriate to think that there was little or limited interaction taking place amongst the hunter-gatherers of the Final Pleistocene. We have shown here that long-term and wide-ranging social networks of exchange and interaction existed within and between regions in the southern Levant and caution that we ought to be careful in how new or unique we consider interaction in the Neolithic, since it is not restricted to sedentary and larger social groups associated with agricultural communities (e.g. Watkins 2008; 2010, 621, 631). Already at 20,000 вр groups in the Levant were engaging in wide-ranging and meaningful social and material exchanges and interactions, which involved sea shells that were considered important due to a combination of their rarity, exotic nature and (symbolic) value, and played a role in wider social negotiations and engagements. Through this they altered the way in which social relationships were forged, maintained and negotiated. This evidence shows that we ought to move away from 
casting pre-Natufian Epipalaeolithic communities in a simplistic 'before and after' perspective. The Neolithic may have been radically different and represent a departure in human development and history, but many critical aspects that are seen to define it were already in place generations before.

\section{Acknowledgements}

Research in the Azraq Basin by the Azraq Basin Early Prehistory Project was funded by the Council for British Research in the Levant and the Wainright Fund. The Epipalaeolithic Foragers in Azraq Project is funded by the Arts and Humanities Research Council. We are grateful to the Department of Antiquities of Jordan for giving permission to carry out research in the Azraq Basin. Comments from two reviewers helped to improve the text considerably. Any omissions or errors are of course our own.

\section{Notes}

1. Olszewski $(2006,24)$ has recently argued that the Nebekian from Yabrud as originally described by Rust (1950) is very similar to Henry's (1995) Qalkhan industry. She points out that Qalkhan points exist in layer 5 at Yabrud and that therefore the Nebekian at Yabrud displays subtle temporal variation over time. In favour of cutting down on existing names for lithic industrial complexes, Olszewski $(2006,25)$ suggests to abandon the term Qalkhan in favour of Nebekian, or to treat the Qalkhan as a sub-facies of the Nebekian. The lithic assemblage from the middle phase of Jilat 6 has produced a strong Qalkhan signature, however, containing many robust La Mouillah and Qalkhan points (Byrd 1998; Byrd \& Garrard 1989; Garrard \& Byrd 1992; Garrard et al. 1994a), suggesting that this is a rather distinct assemblage. The dating of these assemblages is generally confirmed by a series of C14 dates as well as the stratigraphic succession, principally at Jilat 6 and Kharaneh IV.

2. In the case of Kharaneh IV Phase $C$ it has to be pointed out that the published material from this phase is as yet limited, and that this occupation horizon consists of intensely deflated deposits (Maher \& Richter pers. observ. June 2008).

Tobias Richter Department of Cross-Cultural and Regional Studies University of Copenhagen Snorresgade 17-19 2300 Copenhagen $S$ Denmark

Email: t.richter@gmx.com

Andrew N. Garrard Institute of Archaeology University College London
31-34 Gordon Square London WC1H PY

$U K$

a.garrard@ucl.ac.uk

Samantha Allock

School of Geography

Earth and Environmental Sciences Faculty of Science and Technology

8 Kirkby Place

University of Plymouth PL4 8AA

$U K$ samantha.allcock@plymouth.ac.uk

Lisa A. Maher

Leverhulme Centre for Human Evolutionary Studies University of Cambridge

Fitzwilliam St

Cambridge

CB2 1QH

UK

Email:1.maher@human-evol.cam.ac.uk

\section{References}

Allcock, S., 2009. Beyond Trade and Subsistence: the Use of Shell Ornaments to Infer Social Interaction and Increasing Complexity during the Early and Middle Epipalaeolithic, Jordan. Unpublished MSc dissertation, University College London.

Asouti, E., 2006. Beyond the Pre-Pottery Neolithic B interaction sphere. Journal of World Prehistory 20(2-4), 87-126.

Bar-Yosef, O., 1970. The Epipalaeolithic Cultures of Palestine. Unpublished PhD thesis, Hebrew University, Jerusalem.

Bar-Yosef, O., 1981. The Epipalaeolithic complexes in the southern Levant, in Préhistoire du Levant: chronologie et organisation de l'espace depuis les origins jusqu'au VI millénaire, eds. J. Cauvin \& P. Sanlaville. Paris: CNRS, $389-409$.

Bar-Yosef, O., 1987. Late Pleistocene adaptations in the Levant, in The Pleistocene Old World: Regional Perspectives, ed. O. Soffer. New York (NY): Plenum Press, 219-36.

Bar-Yosef, O., 1988. The date of southwest Asian Neanderthals, in L'Homme de Neandertal, vol. 3, ed. M. Otte. Liège: ERAUL, 31-8.

Bar-Yosef, O., 1989. The last glacial maximum in the Mediterranean Levant, in The World at 18,000 BP, vol. 2: Low Latitudes, eds. O. Soffer \& C. Gamble. London: Unwin Hyman, 58-77.

Bar-Yosef, O., 1991. Stone tools and social context in Levantine prehistory, in Perspectives on the Past: Theoretical Biases in Mediterranean Hunter-Gatherer Research, ed. 
G.A. Clark. Philadelphia (PA): University of Philadelphia Press, 353-70.

Bar-Yosef, O., 1998. The Natufian culture in the Levant, threshold to the origins of agriculture. Evolutionary Anthropology 6(5), 159-77.

Bar-Yosef, O., 2001. Lithics and the social geographical configurations identifying Neolithic tribes in the Levant, in Beyond Tools: Redefining PPN Lithic Assemblages of the Levant, eds. I. Caneva, C. Lemorini, D. Zampetti \& P. Biagi. Berlin: Ex Oriente, 437-48.

Bar-Yosef, O., 2002. The Natufian culture and the Early Neolithic: social and economic trends in southwestern Asia, in Examining the Farming/Language Dispersal Hypothesis, eds. P. Bellwood \& C. Renfrew. (McDonald Institute Monographs.) Cambridge: McDonald Institute for Archaeological Research, 113-26.

Bar-Yosef, O., 2004. The Natufian: a complex society of foragers, in Beyond Foraging and Collecting: Evolutionary Change in Hunter-Gatherer Settlement Systems, eds. B. Fitzhugh \& J. Habu. New York (NY): Kluwer Academic Press, 91-152.

Bar-Yosef, O., 2008. Farming, herding, and the transformation of human landscapes in southwestern Asia, in Handbook of Landscape Archaeology, eds. B. David \& J. Thomas. Walnut Creek (CA): Left Coast Press, 315-27.

Bar-Yosef, O. \& A. Belfer-Cohen, 1989. The origins of sedentism and farming communities in the Levant. Journal of World Prehistory 3(4), 447-98.

Bar-Yosef, O. \& A. Belfer-Cohen, 1991. From sedentary hunter-gatherers to territorial farmers in the Levant, in Between Bands and States, ed. S.A. Gregg. Carbondale (IL): Southern Illinois University, 181-202.

Bar-Yosef, O. \& A. Belfer-Cohen, 1992. From foraging to farming in the Mediterranean Levant, in Transitions to Agriculture in Prehistory, eds. A.B. Gebauer \& T.D. Price. Madison (WI): Prehistory Press, 21-48.

Bar-Yosef, O. \& R.H. Meadow, 1995. The origins of agriculture in the Near East, in Last Hunters-First Farmers: New Perspectives on the Prehistoric Transition to Agriculture, eds. T.D. Price \& A.B. Gebauer. Santa Fe (NM): School of American Research Press, 39-94.

Bar-Yosef, O. \& J. Vogel, 1987. Relative and absolute chronology of the Epipalaeolithic in the southern Levant, in Chronologies in the Near East, eds. O. Aurenche, J. Evin \& F. Hours (British Archaeological Reports International Series 379.) Oxford: BAR, 219-46.

Bar-Yosef Mayer, D.E., 1989. Late Palaeolithic and Neolithic marine shells in the southern Levant as cultural markers, in Proceedings of the 1986 Shell Bead Conference, ed. C.F. Hayes. (Research Records 20.) Rochester (NY): Rochester Museum and Science Center, 169-74.

Bar-Yosef Mayer, D.E., 1991. Changes in the selection of marine shells during the transition from the Natufian to the Neolithic, in The Natufian Culture in the Levant, eds. O. Bar-Yosef \& F.R. Valla. Ann Arbor (MI): Monographs in Prehistory, 629-36.

Bar-Yosef Mayer, D.E., 2005. The exploitation of shells as beads in the Palaeolithic and Neolithic of the Levant. Paléorient 31(1), 176-85.
Barnard, A., 2004. Hunting-and-gathering society: an eighteenth-century Scottish invention, in HunterGatherers in History, Archaeology, and Anthropology, ed. A. Barnard. Oxford: Berg, 31-44.

Barrett, J.C., 2001. Agency, the duality of structure and the problem of the archaeological record, in Archaeological Theory Today, ed. I. Hodder. Cambridge: Cambridge University Press, 141-64.

Barrett, J.C. \& K.F. Fewster, 1999. Intimacy and structural transformation: Giddens and archaeology, in Philosophy and Archaeological Practice. Perspectives for the 21st Century, eds. C. Holtorf \& H. Karlsson. Göteborg: Bricoleur Press, 25-58.

Barton, M.C. \& M.P. Neeley, 1996. Phantom cultures of the Levantine Epipalaeolithic. Antiquity 70, 139-47.

Belfer-Cohen, A., 1991. The Natufian in the Levant. Annual Review of Anthropology 20, 167-86.

Belfer-Cohen, A., 1995. Rethinking social stratification in the Natufian culture: the evidence from burials, in The Archaeology of Death in the Ancient Near East, ed. S. Campbell. London: Oxbow, 9-16.

Belfer-Cohen, A. \& O. Bar-Yosef, 2000. Early sedentism in the Near East: a bumpy ride to village life, in Life in Neolithic Farming Communities: Social Organization, Identity and Differentiation, ed. I. Kuijt. New York (NY): Kluwer Academic/Plenum Publishers, 19-37.

Bender, F., 1974. Geology of Jordan. Supplementary edition with minor corrections in English. Berlin: Gebr. Borntraegger.

Betts, A.V.G., 1988. The Black Desert Survey: prehistoric sites and subsistence strategies in eastern Jordan, in The Prehistory of Jordan: the State of Research in 1986, eds. A.N. Garrard \& H.G. Gebel. (British Archaeological Reports International Series 396.) Oxford: BAR, 369-91.

Betts, A.V.G., 1991. The late Epipalaeolithic in the Black Desert, eastern Jordan, in The Natufian Culture in the Levant, eds. O. Bar-Yosef \& F.R. Valla. Ann Arbor (MI): International Monographs in Prehistory, 217-34.

Betts, A.V.G., 1998. The Harra and the Hamad. Excavations and Surveys in Eastern Jordan, vol. 1. Sheffield: Sheffield Academic Press.

Binford, L.R., 1980. Willow smoke and dog's tails: huntergatherer settlement systems and archaeological site formation. American Antiquity 45, 4-20.

Binford, L.R., 2001. Constructing Frames of Reference: an Analytical Method for Archaeological Theory Building Using Ethnographic and Environmental Data Sets. Berkeley \& Los Angeles (CA): University of California Press.

Bourdieu, P., 1977. Outline of a Theory of Practice. Cambridge: Cambridge University Press.

Bourdieu, P., 1990. The Logic of Practice. Cambridge: Polity Press.

Boyd, B., 2001. The Natufian burials from el-Wad, Mt Carmel: beyond issues of social differentiation. Journal of the Israel Prehistoric Society 31, 185-200.

Boyd, B., 2002. Ways of eating/ways of being in the later Epipalaeolithic (Natufian) Levant, in Thinking Through the Body: Archaeologies of Corporeality, eds. Y. Hamilakis, 
M. Pluciennik \& S. Tarlow. New York (NY): Kluwer Academic Press, 137-52.

Boyd, B., 2004. Agency and landscape: abandoning the 'nature/culture' dichotomy in interpretations of the Natufian and the transition to the Neolithic, in The Last Hunter-gatherer Societies in the Near East, ed. C. Delage. (British Archaeological Reports International Series 1320.) Oxford: BAR, 119-36.

Bradley, R., 1984. The Social Foundations of Prehistoric Britain. London: Longman.

Byrd, B., 1988. Late Pleistocene settlement diversity in the Azraq Basin. Paléorient 14(2), 257-64.

Byrd, B.F., 1994. Late Quaternary hunter-gatherer complexes in the Levant between 20,000 and 10,000 B.P., in Late Quaternary Chronology and Paleoclimates of the Eastern Mediterranean, eds. O. Bar-Yosef \& R.S. Kra. Ann Arbor (MI): Radiocarbon, 205-26.

Byrd, B., 1998. Spanning the gap from the Upper Palaeolithic to the Natufian: the early and middle Epipalaeolithic, in The Prehistory of Jordan, ed. D.O. Henry. (British Archaeological Reports International Series 705.) Oxford: BAR, 64-82.

Byrd, B.F. \& A.N. Garrard, 1989. The Last Glacial Maximum in the Jordanian desert, in The World at 18,000 BP, vol. 2: Low Latitudes, eds. O. Soffer \& C. Gamble. London: Unwin Hyman, 78-96.

Byrd, B. \& C.M. Monahan, 1995. Death, mortuary ritual and Natufian social structure. Journal of Anthropological Archaeology 14, 251-87.

Cauvin, J., 1994. Naissance des divinités, naissance de l'agriculture: la Révolution des symboles au Néolithique. Paris: CNRS.

Cauvin, J., 2000. The Birth of the Gods and the Origins of Agriculture. Cambridge: Cambridge University Press.

Clark, G.A., 1996. Plus français que les Français. Antiquity 70(267), 138-9.

Copeland, L. \& F. Hours, 1989. The Hammer on the Rock: Studies in the Early Palaeolithic of Azraq, Jordan. (British Archaeological Reports International Series 540.) Oxford: BAR.

Dobres, M.-A., 2000. Technology and Social Agency: Outlining a Practice Framework for Archaeology. Oxford: Blackwell.

Entwistle, J., 2000. The Fashioned Body: Fashion, Dress, and Modern Social Theory. Cambridge: Cambridge University Press.

Fellner, R., 1995a. Cultural Change and the Epipalaeolithic of Palestine. (British Archaeological Reports International Series 599.) Oxford: BAR.

Fellner, R., 1995b. Technology or typology: a response to Neeley and Barton. Antiquity 69(263), 381-3.

Gamble, C., 2004. Social archaeology and the unfinished business of the Palaeolithic, in Explaining Social Change: Studies in Honour of Colin Renfrew, eds. J. Cherry, C. Scarre \& S. Shennan. (McDonald Institute Monographs.) Cambridge: McDonald Institute for Archaeological Research, 17-26.

Garrard, A.N., 1991. Natufian settlement in the Azraq Basin, eastern Jordan, in The Natufian Culture in the Levant, eds. O. Bar-Yosef \& F.R. Valla. Ann Arbor (MI): Inter- national Monographs in Prehistory, 235-44.

Garrard, A.N., 1998. Environment and cultural adaptations in the Azraq Basin: 24,000-7,000 B.P., in The Prehistory of Jordan, ed. D.O. Henry. (British Archaeological Reports International Series 705.) Oxford: BAR, 139-48.

Garrard, A.N. \& B.F. Byrd, 1992. New dimensions to the Epipalaeolithic of the Wadi el-Jilat in central Jordan. Paléorient 18(1), 47-62.

Garrard, A.N. \& B.F. Byrd, in prep. Beyond the Fertile Crescent: Late Palaeolithic and Neolithic Communities of the Jordanian Steppe, vol. 1. Oxford: Oxbow \& CBRL.

Garrard, A.N., N.P. Stanley Price \& L. Copeland, 1977. A survey of prehistoric sites in the Azraq Basin of eastern Jordan. Paléorient 3, 109-26.

Garrard, A N., B. Byrd, P. Harvey \& F. Hivernel, 1985. Prehistoric environment and settlement in the Azraq Basin: a report on the 1982 survey season. Levant 17, 1-28.

Garrard, A.N., B. Byrd \& A. Betts, 1986. Prehistoric environment and settlement in the Azraq Basin: an interim report on the 1984 excavation season. Levant 18, 5-24.

Garrard, A.N., A. Betts, B. Byrd \& C. Hunt, 1987. Prehistoric environment and settlement in the Azraq Basin: an interim report on the 1985 Excavation Season. Levant $19,5-25$.

Garrard, A.N., A. Betts, B.F. Byrd \& C. Hunt, 1988. Summary of the palaeoenvironmental and prehistoric investigations in the Azraq Basin, in The Prehistory of Jordan. the State of Research in 1986, eds. A.N. Garrard \& H.G. Gebel. (British Archaeological Reports, International Series 396.) Oxford: BAR, 311-37.

Garrard, A.N., D. Baird \& B.F. Byrd, 1994a. The chronological basis and significance of the late Palaeolithic and Neolithic sequence in the Azraq Basin, Jordan, in Late Quaternary Chronology and Paleoclimates of the Eastern Mediterranean, eds. O. Bar-Yosef \& R.S. Kra. Ann Arbor (MI): Radiocarbon, 177-99.

Garrard, A.N., D. Baird, S. Colledge, L. Martin \& K. Wright, 1994b. Prehistoric environment and settlement in the Azraq Basin: an interim report on the 1987 and 1988 excavation season. Levant 26, 73-109.

Garrard, A.N., S. Colledge \& L. Martin, 1996. The emergence of crop cultivation and caprine herding in the 'marginal zone' of the southern Levant, in The Origins and Spread of Agriculture and Pastoralism in Eurasia, ed. D. Harris. London: University College London Press, 204-26.

Giddens, A., 1979. Central Problems in Social Theory: Action, Structure and Contradiction in Social Analysis. London: Macmillan.

Giddens, A., 1984. The Constitution of Society. Outline of the Theory of Structuration. Cambridge: Polity Press.

Goring-Morris, A.N., 1987. At the Edge: Terminal Pleistocene Hunter-gatherers in the Negev and Sinai. (British Archaeological Reports International Series 361.) Oxford: BAR.

Goring-Morris, A.N., 1989. Sociocultural aspects of marine mollusc use in the Terminal Pleistocene in the Negev and Sinai regions of the southern Levant, in Proceed- 
ings of the 1986 Shell Bead Conference, ed. C.F. Hayes. (Research Records 20.) Rochester (NY): Rochester Museum and Research Center, 175-87.

Goring-Morris, A.N., 1995. Complex hunter/gatherers at the end of the Paleolithic, in The Archaeology of Society in the Holy Land, ed. T. Levy. London: Leicester University Press, 141-67.

Goring-Morris, A.N., 1996. Square pegs into round holes: a critique of Neeley and Barton. Antiquity 70(267), 130-35.

Goring-Morris, A.N. \& A. Belfer-Cohen, 1998. The articulation of cultural processes and late Quaternary environmental changes in Cisjordan. Paléorient 23(2), 71-93.

Goring-Morris, A.N., E. Hovers \& A. Belfer-Cohen, 2009. The dynamics of Pleistocene and Early Holocene settlement patterns and human adaptations in the Levant - An overview, in Transitions in Prehistory: Essays in Honor of Ofer Bar-Yosef, eds. J.J. Shea \& D.E. Lieberman. Oxford: Oxbow Books, 185-252.

Gregory, C.A., 1994. Exchange and reciprocity, in Companion Encyclopedia of Anthropology, ed. T. Ingold. London: Routledge, 911-39.

Henry, D.O., 1989. From Foraging to Agriculture: the Levant at the End of the Ice Age. Philadelphia (PA): Philadelphia University Press.

Henry, D.O., 1994. Late Levantine Mousterian patterns of adaptation and cognition, in Prehistoric Cultural Ecology and Evolution: Insights From Southern Jordan, ed. D.O. Henry. New York (NY): Plenum, 107-32.

Henry, D.O. (ed.), 1995. Prehistoric Cultural Ecology and Evolution: Insights from Southern Jordan. New York (NY): Plenum Press.

Henry, D.O., 1996. Functional minimalism versus ethnicity in explaining lithic patterns in the Levantine Epipalaeolithic. Antiquity 70(267), 135-6.

Hodder, I., 1982. Symbols in Action: Ethnoarchaeological Studies of Material Culture. Cambridge: Cambridge University Press.

Hodder, I., 1986. Reading the Past: Current Approaches to Interpretation in Archaeology. Cambridge: Cambridge University Press.

Hodder, I., 2007. Catalhoyuk in the context of the Middle Eastern Neolithic. Annual Review of Anthropology 36, 105-20.

Hole, F., 2002. Is size important? Function and hierarchy in Neolithic settlements, in Life in Neolithic Farming Societies: Social Organization, Identity and Differentiation, ed. I. Kuijt. New York (NY): Kluwer Academic, 137-64.

Hours, F., 1992. Le Paleolithique et L'Epipaleolithique de la Syrie et du Liban. Beirut: Dar el-Machreq Sarl.

Ingold, T., 1992. Foraging for data, camping with theories: hunter-gatherers and nomadic pastoralists in archaeology and anthropology. Antiquity 66, 790-803.

Ingold, T., 2000. The Perception of the Environment: Essays on Livelihood, Dwelling and Skill. London: Routledge.

Jones, S., 1997. The Archaeology of Ethnicity. London: Routledge.

Joyce, R.A., 2005. Archaeology of the body. Annual Review of Anthropology 34, 139-58.

Kaufman, D., 1995. Microburins and microliths of the Levantine Epipalaeolithic: a comment on the paper by Neeley and Barton. Antiquity 69(263), 375-81.

Kaufman, D., 1999. Archaeological Perspectives on the Origins of Modern Humans: a View from the Levant. Westport (CT): Bergin \& Garvey.

Kaufman, D., 2001. Comparisons and the case for interaction among Neanderthals and early modern humans in the Levant. Oxford Journal of Archaeology 20, 219-40.

Kuijt, I., 2000a. Keeping the peace: ritual, skull caching and community integration in the Levantine Neolithic, in Life in Neolithic Farming Communities: Social Organization, Identity and Differentiation, ed. I. Kuijt. London: Kluwer Academic, 137-64.

Kuijt, I., 2000b. People and space in early agricultural villages: exploring daily lives, community size and architecture in the late Pre-Pottery Neolithic. Journal of Anthropological Archaeology 19, 75-102.

Kuijt, I., 2002. Reflections on ritual and the transmission of authority in the Pre-Pottery Neolithic of the southern Levant, in Magic Practices and Ritual in the Near Eastern Neolithic, eds. H.G.K. Gebel, B.D. Hermansen \& C.H. Jensen. Berlin: Ex Oriente, 81-90.

Lave, J. \& Wenger, E., 1991. Situated Learning: Legitimate Peripheral Participation. Cambridge: Cambridge University Press.

Lemonnier, P., 1989. Bark capes, arrowheads, and concorde: on social representations of technology, in The Meaning of Things: Material Culture and Symbolic Expression, ed. I. Hodder. London: Unwin Hyman, 156-71.

Lemonnier, P., 1990. Topsy turvy techniques: remarks on the social representation of techniques. Archaeological Review from Cambridge 9, 27-39.

Lemonnier, P., 1992. Elements for an Anthropology of Technology. Michigan (MI): University of Michigan.

Macumber, P.G., 2001. Evolving landscape and environment in Jordan, in The Archaeology of Jordan, eds. B. MacDonald, R. Adams \& P. Bienkowski. Sheffield: Sheffield Academic Press, 1-30.

Maher, L., T. Richter \& D. Jones, 2007. Archaeological survey at the Epipalaeolithic site of Kharaneh IV. Annual of the Department of Antiquities of Jordan 51, 257-62.

Martin, L., 1994. Hunting and Herding in a Semi-Arid Region. Sheffield: University of Sheffield.

Mauss, M., 1935. Les techniques du corps. Journal de Psychologie 32(3-4), 271-93.

Meskell, L.M., 1999. Writing the body in archaeology, in Reading the Body: Representations and Remains in the Archaeological Record, ed. A.E. Rautman. Philadelphia (PA): University of Pennsylvania, 13-23.

Minar, C.J., 2001. Motor skills and the learning process: the conservation of cordage final twist direction in communities of practice. Journal of Anthropological Research 57(4), 381-405.

Muheisen, M., 1983. La préhistoire en Jordanie. Recherches sur l'Epipaleolithic: l'exemple du Gisement de Kharaneh IV. Bordeaux: Université de Bordeaux.

Muheisen, M., 1988a. The Epipalaeolithic phases of Kha- 
raneh IV, in The Prehistory of Jordan: the State of Research in 1986, eds. A.N. Garrard \& H.G. Gebel. (British Archaeological Reports International Series 396.) Oxford: BAR, 353-67.

Muheisen, M., 1988b. Le gisement de Kharaneh IV, note sommaire sur la phase D. Paléorient 14(2), 265-82.

Muheisen, M., 1988c. Le Paleolithique et l'Epipaleolithique en Jordanie. Unpublished PhD dissertation, Université de Bordeaux.

Muheisen, M. \& H. Wada, 1995. An analysis of the microliths at Kharaneh IV Phase D, Square A20/37. Paléorient 21, 75-95.

Neeley, M.P. \& C.M. Barton, 1994. A new approach to interpreting late Pleistocene microlith industries in southwest Asia. Antiquity 68, 275-88.

Nelson, J.B., 1973. Azraq: Desert Oasis. London: Allen Lane.

Olszewski, D.I., 2001. The Palaeolithic, including the Epipalaeolithic, in The Archaeology of Jordan, eds. B. MacDonald, R. Adams \& P. Bienkowski. Sheffield: Sheffield Academic Press, 31-65.

Olszewski, D.I., 2006. Issues in the Levantine Epipalaeolithic: the Madamaghan, Nebekian and Qalkhan (Levant Epipalaeolithic). Paléorient 32(1), 19-26.

Perrot, J., 1966. Le gisement natoufien de Mallaha (Eynan), Israël. L'Anthropologie 70, 437-84.

Peterson, J., 1999. Early Epipaleolithic settlement patterns: insights from the study of ground stone tools from the southern Levant. Levant 31, 1-17.

Pfaffenberger, B., 1992. Social anthropology of technology. Annual Review of Anthropology 21, 491-516.

Phillips, J.L., 1996. The real nature of variability in Epipalaeolithic assemblages. Antiquity 70(267), 137-8.

Pluciennik, M., 2002. The invention of hunter-gatherers in seventeenth century Europe. Archaeological Dialogues 9(2), 98-151.

Pluciennik, M., 2004. The meaning of 'hunter-gatherers' and modes of subsistence: a comparative historical perspective, in Hunter-gatherers in History, Archaeology and Anthropology, ed. A. Barnard. Oxford: Berg, 17-29.

Rak, Y., 1993. Morphological variation in Homo neanderthalensis and Homo sapiens in the Levant: a biogeographic model, in Species, Species Concepts, and Primate Evolution, eds. W.H. Kimbel \& L.B. Martin. New York (NY): Plenum, 523-36.

Reese, D.S., 1991. Marine shells in the Levant: Upper Palaeolithic, Epipalaeolithic and Neolithic, in The Natufian Culture in the Levant, eds. O. Bar-Yosef \& F. Valla. Ann Arbor (MI): International Monographs in Prehistory, 613-28.

Reese, D.S., 1995. Shells from the Wadi Hisma Sites, in Prehistoric Cultural Ecology and Evolution: Insights from Southern Jordan, ed. D.O. Henry. New York (NY): Plenum Press, 385-90.

Richter, T., 2009a. Marginal Landscapes? The Azraq Oasis and the Cultural Landscapes of the Final Pleistocene Levant, (Papers of the Institute of Archaeology.) London: University College London.

Richter, T., in press. Nebekian, Qalkhan and Kebaran: variability, classification and interaction. New insights from the Azraq Oasis, in Proceedings of the 6th Conference on PPN Chipped and Ground Stone Industries of the Fertile Crescent, Manchester, March 3rd-6th 2008, eds. E. Healey, M. Osamu \& S. Campbell. Berlin: Ex Oriente.

Richter, T. \& C. Röhl, 2006. Rescue excavations at Epipalaeolithic 'Ayn Qasiyah: report on the 2005 season. Annual of the Department of Antiquities of Jordan 50, 189-203.

Richter, T., S. Alcock, E. Asouti et al., 2010a. New light on Final Pleistocene settlement diversity in the Azraq Basin: some preliminary results from 'Ayn Qasiyah and AWS 48. Paléorient 35, 49-68.

Richter, T., J.T. Stock, L. Maher \& C. Hebron, 2010. An Early Epipalaeolithic sitting burial from the Azraq Oasis, Jordan. Antiquity 84, 321-34.

Richter, T., S. Colledge, S. Luddy, D. Jones, M. Jones \& R. Kelly, 2007. Preliminary report on the 2006 season at Epipalaeolithic 'Ayn Qasiyah, Azraq es-Shishan. Annual of the Department of Antiquities of Jordan 51, 313-28.

Rollefson, G.O., 1983. Two seasons of excavation at Ain el-Assad, eastern Jordan, 1980-1981. Bulletin of the American Schools of Oriental Research 252, 25-34.

Rollefson, G., 2004. The character of LPPNB social organization, in Central Settlements in Neolithic Jordan, eds. H.D. Bienert, H.G. Gebel \& R. Neef. Berlin: Ex Oriente, 145-53.

Rollefson, G., D. Schnurrenberger, L. Quintero, R.P. Watson \& R. Low, 1997. Ain Soda and 'Ayn Qasiya: new late Pleistocene and early Holocene sites in the Azraq Shishan area, eastern Jordan, in The Prehistory of Jordan, vol. II: Perspectives from 1997, ed. H.G.K. Gebel, Z. Kafafi \& G.O. Rollefson. Berlin: Ex Oriente, 45-58.

Rollefson, G., L. Quintero \& P. Wilke, 1999. Bawwab alGhazal: preliminary report on the testing season 1998. Neo-Lithics 1/99, 2-4.

Rollefson, G., L. Quintero \& P. Wilke, 2001. Azraq Wetlands Survey 2000: preliminary report. Annual of the Department of Antiquities of Jordan 45, 71-82.

Rust, A., 1950. Die Höhlenfunde von Jabrud. Neumünster: Karl Wacholtz Verlag.

Sassamann, K.E. \& W. Rudolphi. 2001. Communities of practice in the early pottery traditions of the American Southwest. Journal of Anthropological Research 57(4), 407-25.

Schyle, D., 1996. Das Epipaläolithikum und der Übergang zum Neolithikum in der Levante und in Ägypten. (Das Epipaläolithikum des Vorderen Orients 1.) Wiesbaden: L. Reichert

Shanks, M. \& C. Tilley, 1987. Social Theory and Archaeology. Cambridge: Cambridge University Press.

Shea, J.J., 2003. Close encounters: Neanderthals and modern humans in the Middle Palaeolithic Levant. The Review of Archaeology 24, 32-55.

Simmons, A.H., 2007. The Neolithic Revolution in the Near East: Transforming the Human Landscape. Tuscon (AZ): University of Arizona Press.

Stutz, A.J. \& G.F. Estabrook, 2004. Computationally intensive multivariate statistics and relative frequency distributions in archaeology (with an application to the Early 
Epipaleolithic of the Levant). Journal of Archaeological Science 31, 1643-58.

Valla, F.R., 1975. Le natoufien, une culture préhistorique en Palestine. Paris: Gabalda.

Valla, F.R., 1995. The first settled societies - Natufian (12,500 10,200 BP), in The Archaeology of the Holy Land, ed. T. Levy. London: Leicester University Press, 169-90.

Wasse, A. \& G. Rollefson, 2005. The Wadi Sirhan Project: report on the 2002 archaeological reconnaissance of Wadi Hudruj and Jabal Thawra, Jordan. Levant 37, $1-20$.

Watkins, T., 2003. Developing socio-cultural networks. NeoLithics 2/03, 36-7.

Watkins, T., 2008. Supra-regional networks in the Neolithic of Southwest Asia. Journal of World Prehistory 21, 139-71.

Watkins, T., 2010. New light on the Neolithic revolution in south-west Asia. Antiquity 84(325), 621-34.

Wenger, E., 1998. Communities of Practice: Learning, Meaning, and Identity. Cambridge: Cambridge University Press.

Wright, G.A., 1978. Social differentiation in the early Natufian, in Social Anthropology, eds. C.L. Redman, M.J. Berman, E.V. Curtin, W.T.J. Langhorne, N.H. Versaggi \& J.C. Wanser. New York (NY): Academic Press, 210-24.

Wright, K., 1991. The origins and development of ground stone assemblages in late Pleistocene southwest Asia. Paléorient 17(1), 19-45.

Wright, K.I., 1992a. A classification system for ground stone tools from the prehistoric Levant. Paléorient 18(2), 53-81.

Wright, K.I., 1992b. Ground Stone Assemblage Variations and Subsistence Strategies in the Levant, 22,000-5,500 B.P. $\mathrm{PhD}$ dissertation, Yale University. Ann Arbor (MI): University Microfilms.

Wright, K.I., 1994. Ground stone tools and hunter-gatherer subsistence in southwest Asia: implications for the transition to farming. American Antiquity 59(2), 238-63.

Wright, K. \& A. Garrard, 2003. Social identities and the expansion of stone bead-making in Neolithic western Asia: new evidence from Jordan. Antiquity 77, 267-84.

Yates, T., 1993. Frameworks for an archaeology of the body, in Interpretative Archaeology, ed. C. Tilley. Oxford: Berg, 31-72.

\section{Author biographies}

Tobias Richter is currently an Assistant Professor at the University of Copenhagen. He studied archaeology at University College London (PhD 2005-2009) and the University of Wales Lampeter (MPhil 2002-2006, BA 1999-2002). His research interests include the Epipalaeolithic-Neolithic transition in western Asia, lithic technology, social learning theories, landscape archaeology and the post-medieval archaeology of the Persian Gulf.

Andrew Garrard is currently Senior Lecturer at the Institute of Archaeology, University College London. He obtained his $\mathrm{PhD}$ on Palaeolithic food-procurement strategies in the Levant from the University of Cambridge in 1980. He was Assistant Director and subsequently Director of the British Institute at Amman for Archaeology and History (1982-89) and has been a Lecturer at the Institute of Archaeology since 1990. He has directed Palaeolithic and Neolithic survey and excavation programmes in Jordan, Turkey and Lebanon.

Samantha L. Allcock received BA and MSc Archaeology degrees from University College London, in 2008 and 2009 respectively. She is currently studying for a $\mathrm{PhD}$ degree from the University of Plymouth in Geographical Sciences. Her work concentrates on the interactions between Holocene climate variability and past cultures within Turkey, with particular focus on the resilience and adaptability of past people.

Lisa Maher is a Research Associate at the University of Cambridge interested in late Pleistocene and early Holocene hunter-gatherer behaviour in the circum-Mediterranean region. She directs field work at two Epipalaeolithic sites in Jordan and a primary theme of her research involves using geoarchaeology, lithic analysis and mortuary archaeology to examine the interrelationships between people and their environment. 